University of San Diego

Digital USD

Spring 5-21-2016

\title{
African-American Empowerment in the United States Military: Understanding how African Americans are transcending inequality in a post-segregated era (1975-2015)
}

Berry L. Buxton Jr.

University of San Diego

Follow this and additional works at: https://digital.sandiego.edu/theses

Part of the Military History Commons, and the United States History Commons

\section{Digital USD Citation}

Buxton, Berry L. Jr., "African-American Empowerment in the United States Military: Understanding how African Americans are transcending inequality in a post-segregated era (1975-2015)" (2016). Theses. 8. https://digital.sandiego.edu/theses/8

This Thesis: Open Access is brought to you for free and open access by the Theses and Dissertations at Digital USD. It has been accepted for inclusion in Theses by an authorized administrator of Digital USD. For more information, please contact digital@sandiego.edu. 
UNIVERSITY OF SAN DIEGO

African-American Empowerment in the United States Military:

Understanding how African Americans are transcending inequality in a postsegregated era (1975-2015)

A Thesis submitted in partial satisfaction of the requirements for the degree of

Master of Arts in History

by

Berry Lee Buxton, Jr.

Thesis Committee

Michael Gonzalez, Ph.D., Chair

Iris Engstrand, Ph.D. 
The Thesis of Berry Lee Buxton, Jr. is approved by:

Thesis Committee Chair
Thesis Committee Member

University of San Diego

San Diego

2016 
Copyright 2016 Berry Lee Buxton, Jr.

Limitations: No part of this document may be reproduced in any form without the author's prior written consent for a period of three years after the date of submittal.

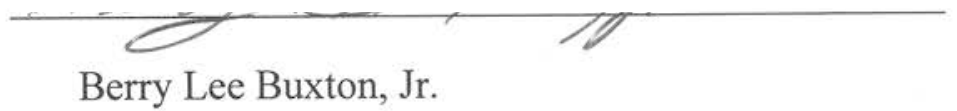




\section{ACKNOWLEDGEMENTS}

Like any literary work such as this, it is something not done alone. There are numerous people that are due my heartfelt gratitude, appreciation, and special thanks:

First I would like to take this opportunity to thank the chair of my committee, Dr. Michael J. Gonzalez. You have been an unlimited reserve of knowledge, support, wisdom and advice during my thesis and graduate studies at USD. "Thank you" does not even begin to convey my appreciation and respect for you in helping me to foster what was initially a very broad idea into this final product. I am truly proud of this work because of you! I am also indebted to Dr. Iris Engstand for her meticulous proof reading, and constructive criticism. During a difficult time in my life, your words of encouragement helped me stay the course. I consider you both a mentor and a friend! Furthermore, I would like to thank Dr. Weeks for teaching me how important it is to be an advocate for social change from the outside in through actions of peace. I give credit to him for helping me to realize that while it is important to speak out against social injustice and inequality, it is also just as important to acknowledge the progress that has been made in those areas as well! I will be forever grateful that all of our paths crossed at USD.

To my brother Jeremy and his wife Reina, you both have been so very supportive in helping me to overcome the many obstacles of single parenthood during this long endeavor. Whenever I expressed doubt or frustration related to the attainment of my graduate degree, you were there to inspire me and pick me back up. For that I just want to say thank you and I couldn't have asked for a better support group to help me complete my thesis.

Last, but certainly not least, I would like to thank my three wonderful children Berry L. Buxton, III, Isaiah C. Buxton and Kayla L. Buxton. All of you have provided me with more motivation and help than you will ever know! Your collective laughter, patience and understanding has helped me to make this thesis what it is now. You're my inspiration and the center of my joy. Daddy will always love you! 


\section{TABLE OF CONTENTS}

Introduction

1.0 American Attitude: Shift in the U.S. Military

1.1 Causations of Social Change.

1.2 Recognizing contributions of African Americans in the military.

2.0 The Power of Legislation

2.1 Changes to military Policy/Programs/Directives

3.0 An era of Black Military inclusion

3.1 Historical Trends: African American Promotions, Achievements and Tributes

4.0 Conclusion

4.1 Appendix

4.2 Bibliography 


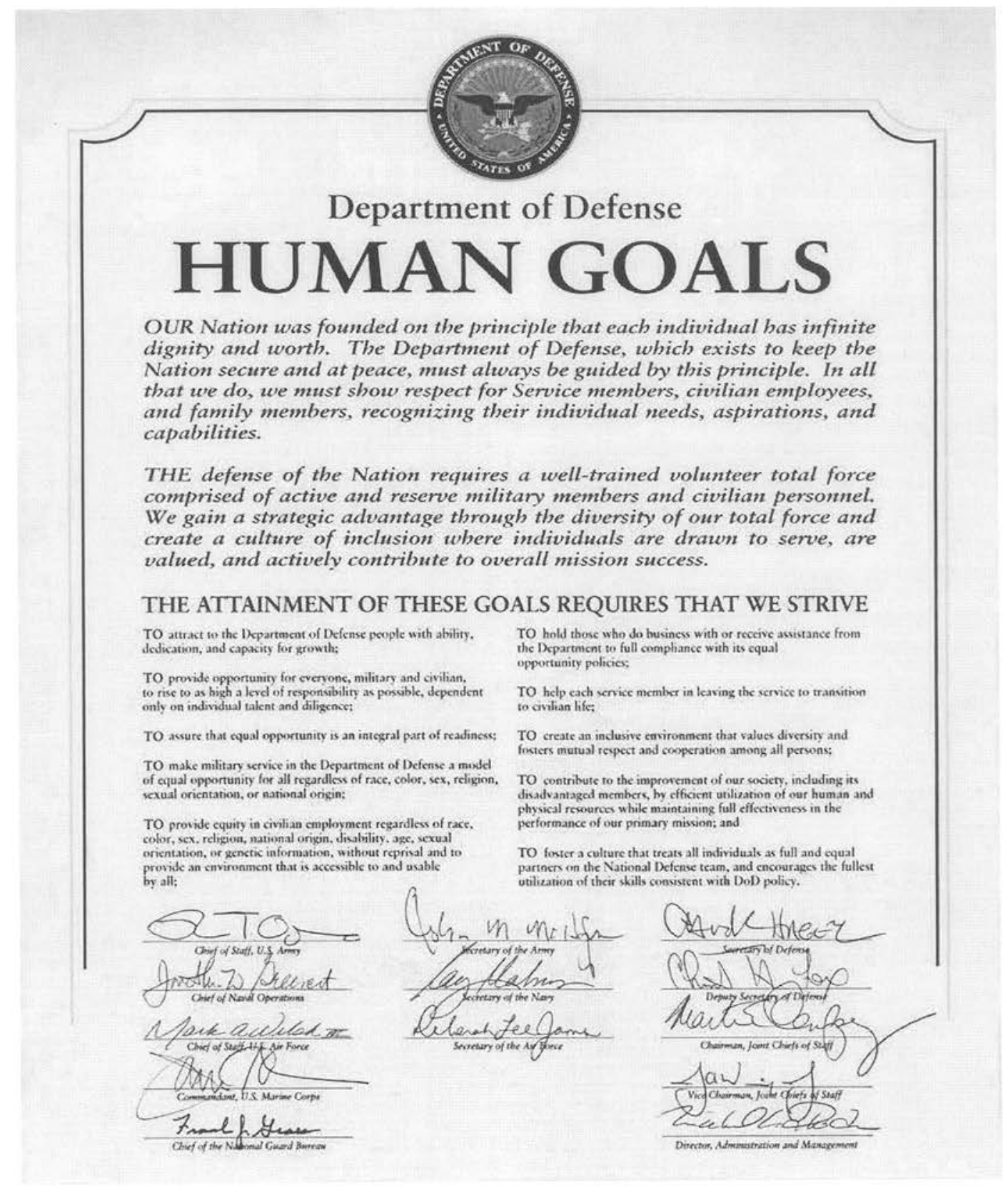

To put into words, according to the DoD Human Goals Charter, which was revised April 28, 2014, this document confirms that "All men are created equal," which is an ideal that America was founded upon. It clearly illustrates that the military has embraced diversity in the twenty-first century by fostering a climate of equality for all Americans in the U.S. military regardless of race or gender. Taken from the Department of Defense Office of Diversity Management and Equal Opportunity, accessed February 6, 2016. (http://diversity.defense.gov/) 


\section{MILITARY ABBREVIATIONS AND ACRONYMS}

All-Volunteer Force - AVF

Defense Race Relations Institute - DDRI

Defense Officer Personnel Management Act - DOPMA

Department of Defense - DoD

Department of Defense Instruction - DoDI

Department of Defense Directive - DoDD

Equal Opportunity - EO

Fleet Master Chief - FLTCM

Master Chief Petty Officer of the Coast Guard - MCPOCG

Morale, Welfare and Recreation - MWR

Sergeant Major of the Marine Corps - SgtMajMC

United States Navy - USN

United States Coast Guard - USCG

Unites States Marine Corps - USMC

Unites States Army - USA

Unites States Air Force - USAF 


\section{Introduction}

Since the American Revolution, African Americans have served in the military. ${ }^{1}$ Although African-American slaves were made free during the Civil War, the rise of Jim Crow in the 1890s made the prospect of equality for African Americans much more difficult to obtain. In 1896, the outcome of the United States Supreme Court case Plessy v. Ferguson resulted in the famous phrase "separate but equal," which remained the law of the land until the 1950s. ${ }^{2}$ Despite segregation, African Americans pushed hard for integration and equality in the U.S. military during WWII. In addition the thesis will show how African Americans empowered transcended in the military after the establishment of the AVF in 1975. Using statistical data and other evidence, this thesis will show that obstacles and barriers that once limited housing, job opportunity and education for African Americans have since been removed within the U.S. military. Throughout this thesis, careful examination will show how desegregation in the military was one of the causes for social change in American society. Furthermore it will illustrate how blacks, who were once thought to be inferior and beneath white Americans intellectually, have been given a greater responsibility of leading and commanding all races within the military after 1975 .

To say that the status of African Americans has not improved as a result of federal efforts in the U.S. military would diminish the work and sacrifices of numerous Civil Rights activists. Therefore this thesis covers a wide variety of

\footnotetext{
${ }^{1}$ The word "African American" is used throughout this work interchangeably with the word "black." The author uses these terms to refer solely to men and women of color.

${ }^{2}$ Plessy v. Ferguson, 163 U.S. 537 (1896).
} 
literature from several scholars that focuses on theories about the Civil Rights Movement and African Americans in the military. Despite public opinion, the social theorist Thomas Sowell believes that the Civil Rights Movement did not have a tremendous impact on the lives of blacks in America. ${ }^{3}$ Indeed it would also appear that many of Sowell's views mirror the ideas that were laid out in the 1965 Moynihan Report, which suggest that the African-Americans' circumstances in the United States are getting worse, not better. Thomas Sowell states "In the period from 1954 to 1964, for example, the number of blacks in professional, technical, and similar high level positions more than doubled." ${ }^{, 4}$ Sowell points out how government equality for blacks has declined after 1965 rather than continuing that upward trend. Sowell's belief is that the Civil Rights legislation has undermined African-American success, especially Affirmative Action. ${ }^{5}$

Dr. Cornell West adds that American democracy was a catastrophic failure up to the 1960s. It would appear that West believes that the real threat impeding the upward mobility, is "nihilism in Black America." ${ }^{, 6}$ West describes black life in America as hopeless, meaningless and with little prospect. West does not believe that government policy/programs have done enough to solve black problems of equality. For example, West criticizes Affirmative Action to say the program is responsible for the loss of black identity and has not brought about enough improvements for black empowerment. ${ }^{7}$ In addition, West comments "this crisis

\footnotetext{
${ }^{3}$ Thomas Sowell, Civil Rights: Rhetoric or Reality? (New York: William Morrow and Company, 1984).

${ }^{4}$ Ibid, 49.

${ }^{5}$ Ibid, 35-61.

${ }^{6}$ Cornel West, Race Matters (Boston: Beacon Press, 1993), 9.

${ }^{7}$ Ibid, 61-68.
} 
of Black leadership contributes to political cynicism among black people; it encourages the idea that we cannot really make a difference in changing our society." ${ }^{8}$ West discounts the large number of successful African Americans saying "this leap in quantity has not been accompanied by a leap in quality. The present day black middle class is not simply different than its predecessors, it is more deficient and, to put it strongly, more decadent." ${ }^{\text {9 }}$ West uses little evidence to support his argument and is considered by some to be a scholar who uses speculation rather than facts. The research presented here will show that African Americans have improved their lot in the United States, especially in the military. In fact, in many respects the military has helped improve the life of African Americans. Moreover, the thesis will present several black leaders in the armed forces with prestigious careers who have served during the period of 1975 to 2015.

Other scholars such as Walter E. Williams would argue that African Americans are still being held back after 1975. Williams says the government stands in the way of African-American progress. He states "There are numerous laws, regulations, and ordinances that have reduced or eliminated avenues of upward mobility for blacks."10 Williams mentions that blacks have become included in a politically flawed system of discrimination that does nothing to change laws that would guarantee equality for blacks. Williams believes that the laws are discriminatory, stating that "they deny full opportunity for the most

\footnotetext{
${ }^{8}$ Ibid, 45.

${ }^{9}$ Ibid, 35-36.

${ }^{10}$ Walter Williams, The State Against Blacks (New York: New Press, McGraw-Hill, 1982), 144.
} 
disadvantaged Americans, among whom blacks are disproportionally

represented." ${ }^{11}$ For example, Williams describes how black youth between sixteen and nineteen years old suffer an unemployment rate three to five times higher than white youth the same age in 1980. Williams' views are dated but for the most part still hold true. In 2015 the unemployment rate for American youth between sixteen and nineteen years old has dropped to 16 percent for whites and 25 percent for blacks. ${ }^{12}$ The untold truth in his example is that the priority for African Americans sixteen to nineteen years old should be towards pursuing education and community involvement, which will better prepare them for college. Educational attainment for African Americans will always be the key that breaks the perpetuating cycle of unemployment in African-American adults. Williams mentions how other ethnic groups have risen above discrimination to obtain equality without help from the "State."13

To say that "Affirmative Action" has hindered or diminished progress for black opportunity in America is not entirely accurate. The first notable contribution to Affirmative Action for blacks in the military came from President Franklin Roosevelt's Executive Order 8802, which prohibited discrimination in the government and led to the integration of blacks in the military. President Harry S. Truman's speech to Congress in 1948 for Executive Order 9981 was just as significant. He said:

\footnotetext{
${ }^{11}$ Ibid, 125.

${ }^{12}$ U.S. Department of Labor, Bureau of Labor Statistics, Employment status of the civilian population by race, sex and age (http://www.bls.gov/news.release/empsit.t02.htm).

${ }^{13}$ Walter Williams, The State Against Blacks (New York: New Press, McGraw-Hill, 1982).
} 
If we wish to inspire the peoples of the world whose freedom is in jeopardy, if we wish to restore hope to those who have already lost their civil liberties, if we wish to fulfill the promise that is ours, we must correct the remaining imperfections in our practice of democracy. ${ }^{14}$

President Truman basically acknowledges that much change is required if America is ever to become a better society that so many yearn for. In 1948, Congress passed the Women's Armed Services Integration Act which granted women permanent status in the armed forces. The Navy and Coast Guard were among the first to discontinue their separate units for women in 1948.

Collectively the Executive Orders of Presidents Franklin D. Roosevelt and Harry

$\mathrm{S}$. Truman were the initial ladder rungs that African Americans used to climb towards upwards mobility militarily and socially.

Jack Foner describes the racial problems blacks endured in the military after 1965. He says that while it may appear that blacks overcame overt racism, prejudice continued to plague blacks in the military after $1965 .{ }^{15}$ Foner suggests that desegregation in the military has not really eliminated discrimination. His argument suggests that for blacks, the military was not viewed as an opportunity for upward mobility after the Civil Rights era. For example, Foner believes the unemployed blacks who joined the armed forces were discriminated against during the Vietnam War. He says that in 1967, 64 percent of eligible blacks were drafted for Vietnam compared to only 31 percent of eligible whites. It is worth mentioning that his argument is directly correlated to Project 100,000 , also known

\footnotetext{
${ }^{14}$ Harry S. Truman, Special Message to the Congress on Civil Rights, Truman Library, 1948, http://www.trumanlibrary.org/publicpapers/index. php?pid=1380st=st1=

${ }^{15}$ Jack D. Foner, Blacks and the Military in American History (New York: Praeger, 1974).
} 
as the "McNamara's 100,000."16 The program was instituted in 1966 for two basic reasons: first, to provide more troops for the military in an effort to relieve the pressures on draft quotas; second, to provide economic opportunity for poor men from underprivileged circumstances. ${ }^{17}$ Foner, like others, seems to assume the military's intention of the project was to be racist.

While pointing out how significant the loss of black life was, it appears that Foner somehow deflected the attention away from whites. Foner mentions that by 196720 percent of Army fatalities and 10 percent of Marine Corps fatalities were blacks in Vietnam. ${ }^{18}$ While the data that Foner uses to support his argument for black fatalities is accurate, he does not include the entire picture. It is important to note that by early 1967, the Army had 20 percent African Americans; in Vietnam they comprised about 13 percent of the 272,000 Army personnel. At the same time, seven percent of the 74,000 Marines in Vietnam were African Americans. ${ }^{19}$ The reason Vietnam suffered more fatalities was because of the combat operations that required soldiers on the ground. It is true that of the 11,000 plus American deaths in 1967, blacks made up 12.5 percent. $^{20}$ What is also true is that of the 58,220 total fatal casualties in the Vietnam War, 7,243 were black and 49,830 were white. ${ }^{21}$ The research shows that the death of

\footnotetext{
${ }^{16}$ Robert S. McNamara, The Essence of Security: Reflection in Office (New York: Harper \& Row, 1968).

${ }^{17}$ Ibid, 131-138.

${ }^{18}$ Foner, Blacks and the Military, 204.

${ }^{19}$ William F. Buckley, Jr., "Army Casualties in South Vietnam by Race" National Review, April 18, 1967.

${ }^{20} \mathrm{http}: / /$ www.archives.gov/research/military/vietnam-war/casualty-statistics.html\#category

${ }^{21}$ Defense Manpower Data Center, https://www.dmdc.osd.mil/dcas/pages/report_vietnam _sum.xhtml
} 
both whites and blacks was significant in Vietnam and proportional to the size of the population.

Examining Foner's perspective after desegregation, it was not until the Korean Conflict (1950-1953) that blacks were actually being used in all major combat operations, while their enlistment and retention numbers still remained low. Even in Korea, the number of American deaths was not properly accurate simply because the military reporting procedures did not differentiate by race in the $1950 \mathrm{~s} .{ }^{22}$ Foner does not acknowledge that the Department of Defense (DOD) data for Korea was flawed. Thus, without knowing the statistical breakdown of the 36,574 casualties in Korea for blacks and whites, some scholars could argue that the statistics for blacks remained the same in combat involvement and deaths. $^{23}$

The scholars listed above have overlooked the success of African Americans in the military. Furthermore, they have discounted that the military has often taken the lead to address discrimination. Overall, they have failed to show how the success of blacks to overcome overt racism and disadvantages affiliated with discrimination was due to the Civil Rights Movement.

The other argument, offered by historians like Gerald Astor, Sherie Morshon, Steven Schlossman and Morris J. MacGregor, examine a shift in American ideology and within the military that indeed resulted from the Civil

\footnotetext{
${ }^{22}$ Staff Sgt. Kathleen T. Rhem, "Korean War Death Stats Highlight Modern DoD Safety Record," American Forces Press, June 8, 2000.

${ }^{23}$ Defense Manpower Data Center, https://www.dmdc.osd.mil/dcas/pages/report_korea _sum.xhtml
} 
Rights Movement. This shift after 1975 created an upward trend of unifying the American nation through the armed forces with equality under the very essence of what the Declaration of Independence originally intended, which stated "that all men are created equal, that they are endowed by their Creator with certain unalienable Rights, that among these are Life, Liberty and the pursuit of Happiness. ${ }^{24}$ To this point, historian Gerald Astor's approach to the idea of equality surrounding African Americans examines the entire struggle to fight alongside fellow Americans in every war to defend their nation. Astor begins his examination for blacks in the military starting with the American Revolution while examining the changes in every war up until the post-Vietnam era. ${ }^{25}$ Aster observes the impact that government officials and legislation has played in granting African Americans the same opportunity as whites for their patriotism. Astor says that the military followed the Civil Rights Movement. It is clear that the government alone would not have acted to improve the situation of blacks in the twentieth century. In the interest of protecting the nation and being pressured so intensely by activists affiliated with the Civil Rights Movement, change was destined to come.

The language used by Astor clearly shows how the champions for black equality in the military have evolved over the past 200 years. Aster's account of equality includes a perspective of equal opportunity and race relations by both black and white members of the armed forces. Astor describes how African-

\footnotetext{
${ }^{24}$ The Library of Congress, http://www.loc.gov/rr/program/bib/ourdocs/Declarlnd.html

${ }^{25}$ Gerald Astor, Right to Fight: A History of African Americans in the Military (Cambridge, MA: Da Capo Press, 1998.)
} 
Americans have begun to overcome discrimination in the military with increased opportunity and responsibility. The research in this thesis will go beyond the postVietnam examination by Astor to highlight the continued empowerment of African Americans in the military from 1975 until 2015 in a variety of different ways.

Sherie Mershon and Steven Schlossman argue that the discrimination African Americans struggled to overcome in the military peaked between 1890 and the $1940 \mathrm{~s}^{26}$ An example of hostility which hindered racial integration in the Marines came from individuals like the Marine Corps Commandant, Major General Thomas Holcomb who told the Navy General Board in 1941 "If it were a question of having a Marine Corps of 5,000 whites or 250,000 Negroes, I would rather have the whites. ${ }^{, 27}$ Mershon and Schlossman reiterate their perspective that blacks have continued to overcome stereotypes of inferiority and ignorance.

Mershon and Schlossman illustrate a decline in prejudice and racial discrimination in the military after 1940 through the $1960 \mathrm{~s}$ in three phases. The first phase began with President Franklin D. Roosevelt from 1940 through the end of World War II in 1945. The military prevented real equality for blacks by integrating the military without completely eliminating discrimination and segregation. ${ }^{28}$ During that time the military adopted the idea of "separate but equal," and used it to say that segregation was not discrimination. ${ }^{29}$ Even though

\footnotetext{
${ }^{26}$ Sherie Mershon and Steven Schlossman. Foxholes \& Color Lines: Desegregating the U.S. Armed Forces (Baltimore: The John Hopkins University Press, 1998.)

27 Ibid, 47.

${ }^{28}$ Ibid, 25.

${ }^{29}$ Ibid, 2.
} 
blacks' housing situations improved, they were far from equal as compared to whites. President Truman was responsible for the second phase with desegregation, which "overlapped with the first and spanned a roughly ten year period from 1943-1954. ${ }^{30}$ Mershon and Schlossman perceive the third phase being "from mid-1950s to the mid-1960s, the armed forces gradually removed lingering restrictions on the assignment and deployment of blacks and began to deal with the sensitive subject of discrimination against black military personnel in towns near military bases. ${ }^{31}$ Still some who would "doubt" the impact of Civil Rights legislation. But it is important to note that the Civil Rights Act of 1964, that supported the integration efforts of the Department of Defense (DOD), began easing the hardships of black military service members in a post-segregated era.

Despite the many definitions for "equality" throughout this thesis, the term will refer to African Americans being treated fairly, equally and no less favorably. Equality also removes discrimination in all areas specific to African American needs, regardless of race. Since the term "equality" can encompass so many different meanings, this thesis will focus on the following: housing, promotions, opportunity, responsibility and justice in the military. The basic idea of equality, including the very principles from which it was founded upon, has changed dramatically since integration first began under President Franklin D. Roosevelt's administration.

Reflecting on the past is helpful in order to understand how much blacks have progressed in the military. In the early nineteenth century skilled black

\footnotetext{
${ }^{30}$ Ibid, 12.

${ }^{31} \mathrm{lbid}, 12$.
} 
journalists worked with the National Association for the Advancement of Colored People (NAACP), to fight for racial justice and equality in the United States. Black journalists worked with numerous leaders within the Civil Rights Movement such as A. Philip Randolph, Walter F. White, and T. Arnold Hill. Together, they were a constant that significantly influenced blacks as a political force, particularly their votes in presidential elections. Because A. Philip Randolph, Walter F. White and T. Arnold Hill used World War II to promote Civil Rights, journalists took up the cause. ${ }^{32}$

Journalists helped to decide the future of blacks in the military and also aided in changing the status of blacks in American society. As stated by Morris J. MacGregor, "They represented a black community that for the most part lacked the cohesion, political awareness, and economic strength which would characterize it in the decades to come." ${ }^{, 33}$ The journalists helped blacks to realize that while fighting for freedom overseas was important, the fight for equality in America was more important. The monthly publication, The Crisis, expressed the sentiment of black equality and the importance of abolishing Jim Crow constantly.

It was President Franklin D. Roosevelt (FDR) who laid the groundwork for such a transformation to take place in the military. In 1941 President Roosevelt established the Fair Employment Practice Committee (FEPC). The

\footnotetext{
${ }^{32}$ Morris J. MacGregor, Integration of the Armed Forces, 1940-1965 (Charleston: Create Space, 2014), 37-38.

${ }^{33}$ Ibid, 36.
} 
purpose of the FEPC was to provide equal opportunity for blacks seeking employment without fear of discrimination.

Not being able to fully ascertain why President Roosevelt signed the order, it can only be perceived that he wanted to suspend the March on Washington Movement (MOWM) in 1941. The MOWM was a protest to end segregation in the armed forces. Had Executive Order 8802 not been implemented, the MOWM would have most certainly happened, and would cause FDR to lose the Democratic black vote in 1944. In 1936 and 1940 President Roosevelt received nearly 70 percent of the black vote, which helped him to win both re-elections by a landslide. ${ }^{34}$

The economic and humanitarian proposals offered by President Roosevelt's New Deal is the reason many black voters shifted from the Republican Party to the Democratic Party in 1936. After shifting political parties in 1936, African Americans were committed to the Democratic Party in an effort to support "important phases of the integration of the Negro into military aspects of the national defense program." ${ }^{35}$ Yet many blacks were still not pleased that their Civil Rights were not fully supported by President Roosevelt. The President feared angering his white constituents and never "sufficiently challenged Southern traditions of white supremacy to create problems for himself." ${ }^{36}$ Although the idea of integration in the Army and Navy began in 1939 according

\footnotetext{
${ }^{34}$ David A. Bositis, Blacks and the 2004 Democratic National Convention (Washington, DC: Joint Center for Political and Economic Studies, 2004), Table 1, Presidential vote and party identification of black Americans, 1936-2000, 9.

${ }^{35}$ MacGregor, Integration of the Armed Forces, 47.

${ }^{36}$ Frank Freidel, F.D.R and the South (Baton Rouge: Louisiana State University Press, 1965), 71102.
} 
to White "the president had apparently never considered the use of integrated units, but after some discussion he seemed to accept the suggestion. ${ }^{, 37}$ Thus the integration of the military by President Roosevelt was not done solely for moral reasons but rather to ensure his re-election as President of the United States for a third and fourth consecutive term.

African Americans on active duty in the military were typically assigned to be cooks, construction workers, or deck seaman. Although all branches of the Armed Forces were ordered by the Commander-in-Chief to adopt policies of integration and equal rights for black service members, they were not widely implemented or enforced in 1941. In fact, the 800,000 African Americans who served in the armed forces during World War II were segregated, especially in the Army. ${ }^{38}$

Eventually, the pressure that Civil Rights activists put on the Department of Defense to integrate worked. On ships, the first branch of the Armed Forces to integrate was the Coast Guard. The Navy soon followed suit with the destroyer USS Mason (DE-529) and submarine chaser USS PC-1264, which were two ships manned with largely African-American crews during World War II. ${ }^{39}$ Even though the Marine Corps was technically a component of the Navy, it had no blacks in its ranks until August 26, 1942. Even though many white officers during the early 1940s shared similar viewpoints that blacks were inferior, some white officers believed that blacks deserved more.

\footnotetext{
${ }^{37}$ MacGregor, Integration of the Armed Forces, 47.

38 Ibid, 114.

${ }^{39}$ Ibid, 150.
} 
In 1941, the "Tuskegee Experiment" was born and gave blacks an opportunity to fly in the military. By 1943 over 77,500 blacks had enlisted in the AAF in nine separate units. ${ }^{40}$ Even though many blacks enlisted to fly, blacks serving in the $99^{\text {th }}$ Pursuit Squadron and the $332^{\text {nd }}$ Fighter Group were the only ones to see in any real combat action. ${ }^{41}$ The Tuskegee Airmen, as trailblazing aviators, were a beacon of hope in the fight to end segregation for blacks in all branches of the armed forces.

Ultimately the acceptance of African Americans during wartime resulted from the military's pressing need for more manpower, especially with soldiers in infantry units after the attack on Pearl Harbor. By 1942 there were 399,454 blacks in the Army which was estimated to be 7.95 percent of all enlisted troops. ${ }^{42}$ Many Civil Rights activists helped break down the stereotypes that blacks were incapable of flying for the Army Air Force (AAF) during WWII. The research will show how the employment of blacks in the military changed.

Until the 1950s, there has always been a "quota" for blacks in the military. Even though the quota for black men was low, it was even lower for black women. The quota for black women enlisting in the Women's Army Auxiliary Corps (WAAC) was 56 in 1941. The WAAC, which soon converted to the Women's Army Corps (WAC) during World War II eliminated the quota for black women nurses in 1944. By 1945, black women were serving in the Navy

\footnotetext{
${ }^{40}$ Ibid, 68.

${ }^{41}$ Ibid. 69.

${ }^{42}$ MacGregor, Integration of the Armed Forces, 61.
} 
WAVES (Women Accepted for Volunteer Emergency Service) and the Coast Guard SPARS.

Entering the early twenty-first century, this thesis will show the struggle many African Americans endured while serving in the U.S. military during the early stages of integration. Despite the barriers and mistreatment they were subjected to, blacks wanted to show their patriotism to their counterparts in the armed forces. The research will highlight the increased responsibility and promotions of African Americans in the military after 1975. Furthermore, the research will show how equal opportunity for African Americans in the military eventually changed the very fabric of American society as well. Examples in this study will illustrate the profound effect military desegregation had on American society and helped unify the nation. While race has always been a delicate topic to discuss in the United States, I believe all Americans and historians benefit from learning about the Civil Rights Movement in the military.

My thesis is divided into four chapters. Chapter one gives a historical overview of how the fight for equality in the military to end segregation was a catalyst for social change in American society. It also illustrates a shift in American attitude which is demonstrated by white and black Americans working together to confront and correct past injustices towards blacks in the military. Chapter two discusses how Civil Rights legislation enabled blacks to overcome discrimination that once hindered them from obtaining equal and fair treatment in the military. The changes to Department of Defense Directives and Instructions with housing, education, recreation, career opportunities and other aspects of 
military life recognized the equality African-American military personnel deserved. Chapter three focuses on statistical data that show numbers of blacks in the military. It will also show the historical trends of African American promotions in the military and how successful they have become after 1975.

Chapter four concludes with a summary analysis of African-American empowerment in the U.S military using Census Data and figures tabulated by the Pentagon and U.S. Government. 


\section{Chapter One}

The Shift in American Attitude: 1951-2015

This chapter explores the change in psychology within the U.S. military in the twentieth century while illustrating how the improvement of AfricanAmerican equality in the military helped to influence American society. Since desegregation of the military African Americans have fought against the idea of white supremacy and inferiority as members of the armed forces. In the years following the Korean Conflict, many senior officers in the armed forces began formally expressing that their perceptions and feelings about black service members had changed. In fact, General Matthew B. Ridgway, who was the Far East Commander, made a formal request in 1951 stating that "he wanted the Twenty-Fourth Infantry Regiment, his major black unit, broken up and its members distributed throughout the white units in his command."1 This chapter acknowledges that while the Civil Rights Movement was not always pleasant, it helped to propel the nation toward integration and equality. Furthermore, to understand just how much the attitude of Americans has changed since 1975, this chapter will examine key events that took place after the establishment of the military's All Volunteer Force (AVF).

Prior to the 1950 s the military followed American society by applying the same restrictive practices to African Americans. Yet by 1954 the military began taking the lead to provide equal opportunities for blacks. This was evident in 1954

\footnotetext{
${ }^{1}$ Bernard C. Nalty and Morris J. MacGregor, Blacks in the Military: Essential Documents (Deleware: Scholarly Resources Inc., 1981), 309.
} 
when Secretary of Defense Charles E. Wilson announced "that the last segregated unit in the military had been eliminated." In fact, prior to the Brown v. Board of Education Supreme Court decision on May 17, 1954, which struck down racially segregated schools as unconstitutional, this fight had already begun for the military in the early 1950s. It was Secretary of Defense Charles E. Wilson who ended the segregation of all schools on military bases. In a policy memorandum submitted January 12, 1954, Secretary Wilson stated the following:

The operation of all school facilities located on military instillations shall be conducted without segregation on the basis of race or color. Effective as of the date of this memorandum, no new school shall be opened for operation on a segregated basis, and schools presently so conducted shall cease operating on a segregated basis, as soon as practicable, and under no circumstances later than September 1, 1955. ${ }^{3}$

The above passage shows how the idea of "separate but equal," in accordance with the 1896 Plessy v. Ferguson decision, had been dismissed by the military before it was abolished within American society. Furthermore, the minority opinion of Judge Charles Fahy of the U.S. Court of Appeals reflects that military success with integration and the initial actions taken to secure equality for blacks in schools was truly influential in the Brown decision. ${ }^{4}$ It was not until sixteen years later in 1970 when all public schools across the nation were finally

\footnotetext{
2 Ibid, 314.

${ }^{3}$ Memorandum, Sec. of Defense Charles E. Wilson for secretary of the army et al., 12 January 1954, subject: Schools on military installations for dependents of military and civilian personnel, General Archives Branch, Washington National Records Center, Suitland, MD.

${ }^{4}$ Adam Yarmolinsky, The Military Establishment: Its Impact on American Society (New York: Harper \& Row Publishers, 1971), 350.
} 
integrated. During the following years the status of black equality continued to change in the military and in the social realm of American society.

In the 1960s, Secretary of Defense Robert McNamara believed that if given enough time the military could be an effective instrument to integrate the nation. ${ }^{5}$ Rather than tackle the problems of discrimination head on, he wanted the military to make American society address the problem of race against African Americans that were helpless to discrimination. ${ }^{6}$ This opinion was shared by President John F. Kennedy and some of his closest council members, who believed that it was impossible to get Congress to approve any Civil Rights legislation and therefore believed that the key to persuasion rested in the military changing first. ${ }^{7}$ As a result, Secretary McNamara made it the responsibility of all Commanders through Department of Defense Directive 5120.36 to take a stand against all discriminatory practice off base in nearby communities to ensure that every service member and their dependents were treated with equality. ${ }^{8}$ Although a difficult task to accomplish, by 1963 in cities all over the country near military bases "restaurants, bars, taxi services, even bathing beaches near military bases were desegregated." $"$

Another form of discrimination that the military helped to resolve was in the medical field with the segregation of blood. In 1942 the American Red Cross

\footnotetext{
${ }^{5}$ Morris MacGregor, "Armed Forces Integration-Forced or Free?" in David Maclsaac, ed., The Military and Society (Washington: Office of Air Force History, 1975), 137.

${ }^{6}$ Robert S. McNamara, The Essence of Security: Reflections in Office (New York: Harper \& Row, 1968), 124.

${ }^{7}$ MacGregor, Armed Forces Integration, 133.

${ }^{8}$ Yarmolinsky, The Military Establishment, 352.

${ }^{9}$ Ibid, 352.
} 
established a policy that would segregate the blood donations of Blacks and Whites. ${ }^{10}$ Despite being informed by Congressman Vito Marcantonio of New York that scientifically there was no difference in the blood of blacks and whites, the Red Cross continued the practice. ${ }^{11}$ What makes this entire process ironic is that research shows that Dr. Charles Drew, an African American doctor, was responsible for organizing the first large-scale blood during WWII. After discovering that the military would separate white and black blood Dr. Drew resigned from his job at the American Red Cross. ${ }^{12}$ Sharing the views of many Civil Rights Activist Dr. Drew gave a profound speech in 1944 when the NAACP honored him with the Spingarn Medal for his achievement in blood plasma and collection. He said:

It is fundamentally wrong for any great nation to willfully discriminate against such a large group of its people. One can say quite truthfully that on the battlefields nobody is very interested in where the plasma comes from when they are hurt. It is unfortunate that such a worthwhile scientific bit of work should have been hampered by such stupidity. ${ }^{13}$

The previous passage is a true reflection of why it did not take the military long to adopt the view that military personnel could receive blood that was not from

\footnotetext{
${ }^{10}$ Dwight Jon Zimmerman, "The American Red Cross African-American Blood Ban Scandal," Defense Media Network, January 21, 2012. http://www.defensemedianetwork.com/stories/theamerican-red-cross-african-american- blood-ban-scandal/

11 Ibid.

${ }^{12}$ U.S. National Library of Medicine, The Charles R. Drew Papers: Becoming "the Father of the Blood Banks," 1938-1941, http://profiles.nlm.nih.gov/ps/retrieve/Narrative/BG/p-nid/338 ${ }^{13}$ Ibid.
} 
someone of the same race. ${ }^{14}$ Even though segregation in the medical field was a common practice in American society in the 1940s, President Harry S. Truman issued Executive Order 9981 in 1948 that ended segregation in hospitals for military personnel. With the American Red Cross still practicing segregation, the Department of Defense created its own National Blood Program in 1952 using its own military personnel to collect blood for the facilities. ${ }^{15}$ It wasn't until called upon by President Truman during the Korean War that the American Red Cross followed suit and finally established an effective integrated blood donor program to support the war effort and all wounded personnel. ${ }^{16}$ By the early 1950s it was obvious that the decision by the American Red Cross to discontinue the segregation of blood was influenced by war itself.

It is imperative to recognize that when it came to the Civil Rights Movement, the patriotism and sacrifice of African Americans during times of war was very inspiring. ${ }^{17}$ While no one can deny the motivating factor of black injustice for Dr. Martin Luther King, Jr's March on Washington in 1963, there is no denying that it was also inspired by the reaction to African American veterans no longer willing to tolerate unequal treatment in civilian life. Dr. King's "I have a dream" speech had a profound effect on President John F. Kennedy. President Kennedy realized that it was time to create legislation that would secure the same rights for blacks in American society that resembled those of blacks on active

\footnotetext{
${ }^{14}$ Louise Cavagnaro and Anne Bennett Swingle, "A History of Segregation and Desegregation," DOME, The Johns Hopkins Medical Institutions, Vol. 55, No. 7, September, 2004.

${ }^{15}$ The American Red Cross, http://www.redcross.org/about-us/history/red-cross-americanhistory/korean-war

${ }^{16}$ Ibid.

${ }^{17}$ Henry Louis Gates Jr., "What Was Black America's Double War?” May 24, 2013, 3. http://www.theroot.com/articles/history
} 
duty in the military in 1963. Even after the assassination of President Kennedy, the promises he made to the NAACP for black equality were honored by President Lyndon B. Johnson when he signed the Civil Rights Act of 1964 into law.

As required by Title VI of the Civil Rights Act of 1964, change was implemented that would finally put an end to racial discrimination and segregation in public and private medical care. ${ }^{18}$ It threatened to withhold federal funding from any hospital that discriminated against blacks. This meant that blacks in need of medical attention could now be treated at any hospital instead of black only hospitals like before under Jim Crow laws. Additionally, it ensured that African Americans never again had to fear the injustice of being part of unethical experiments like the Tuskegee Syphilis Study which was initiated by the U.S Public Health Service in Alabama in $1932 .{ }^{19}$ This was an experiment to see what would happen to African American males if their syphilis infections went untreated. Even after penicillin became available in 1950, the 400 black men that were being monitored and studied with the disease were denied the medicine which led to the deaths of over 100 of them. ${ }^{20}$ Such an atrocity upset many black military officers and noncommissioned officers returning home from war since medical treatment and hospitals in the military were already integrated by the late 1940s. Eventually, Peter Buxtun, a venereal disease investigator and former army

\footnotetext{
${ }^{18}$ David Barton Smith, Health Care Divided: Race and Healing a Nation (Ann Arbor: University of Michigan Press, 1999), 101.

${ }^{19}$ Susan M. Reverby, Examining Tuskegee: The Infamous Syphilis Study and Its Legacy (Chapel Hill: University of North Carolina Press, 2009), 1-2.

${ }^{20}$ Ibid.
} 
medic, was the crusader that exposed the injustice of this experiment and disclosed documents that finally brought it to an end in $1972 .{ }^{21}$ What is clear today unlike in decades past, is that African Americans are no longer being denied access to proper medical treatment in hospitals around the country due to the color of their skin.

Over time, the quest for military equality continued to influence the civilian realm of the United States. One way military integration and the fight for equality shaped American society was through the reflection of national values. ${ }^{22}$ Additionally there was a sense of national guilt that continued to transfer from the military to society for the mistreatment of African-American veterans returning home after fighting for freedom and democracy abroad. An example of such guilt about the treatment of blacks was expressed by white military officers who told President Lyndon Johnson that in Vietnam it was a disgrace that young African Americans had to fight for freedom overseas they would never get at home. ${ }^{23}$ Events in the military were moving much faster and beyond those in society. Another example of this was evident by Secretary McNamara during his last years in office when he initiated his open-housing campaign in 1967 to improve housing for blacks in the military. ${ }^{24}$ Even though only 31 percent of housing off base was available to African Americans in 1967, by 1968 there was over 90 percent of the off base housing available to African Americans. ${ }^{25}$ The continued

\footnotetext{
${ }^{21}$ Ibid, 76-84.

${ }^{22}$ Yarmolinsky, The Military Establishment, 7.

${ }^{23} \mathrm{Ibid}, 342$.

${ }^{24}$ MacGregor, Armed Forces Integration, 137.

${ }^{25}$ McNamara, The Essence of Security, 126-127.
} 
efficiency of military progress towards equality inspired President Johnson to use the power of the Executive Branch to pass the Civil Rights Act of 1968 which finally guaranteed housing equality for all African Americans across the nation.

Ironically from a demographic standpoint in the 1970s, many white Americans were reluctant to live in neighborhoods with blacks. In 1976, 41 percent of white Americans were willing to move away from their neighborhoods if even just one black family moved in. ${ }^{26}$ Research has shown that cities with a large military presence made integration easier and more acceptable beginning in the 1980 s. Cities with military integration in neighborhoods practiced less discrimination towards blacks according to a study by demographers Reynolds Farley and William Frey. ${ }^{27}$ The study conducted by Farley and Frey analyzed 232 metropolises in which there were 20,000 or more blacks or in which blacks made up 3 percent or more of the population. ${ }^{28}$ They analyzed data for block groups that averaged 903 residents in 1980 and 564 in $1990 .^{29}$ To measure segregation Farley and Frey used a block group index for data that took a minimum value of zero to its maximum value of one hundred. The data in Table 1 gives a more realistic picture of segregation with the metropolis with the smallest numbers being the least segregated and metropolis with the highest numbers being the most segregated.

${ }^{26}$ Reynolds Farley and William H. Frey, "Changes in the Segregation of Whites From Blacks During the 1980s," American Sociological Review, Vol. 59, No. 1 (February 1994), 28.

${ }^{27}$ Ibid, 23-45.

${ }^{28}$ Ibid, 30.

${ }^{29}$ Ibid. 
Although Civil Rights legislation was passed in 1968 to guarantee housing equality for African Americans, black military families living in communities helped to diminish the fear and resistance to integration across the nation. This was obvious in communities with economies dependent on the military in Virginia, Washington, Florida, Texas, Georgia, and California. ${ }^{30}$ Table 1 shows the cities (metropolises) with the lowest and highest levels of segregation as reported by the U. S. Bureau of the Census in 1980 and 1990. It is one thing to argue that these changes were simply a coincidence but the data in Table 1 suggests that segregation levels were strongly linked to the economics and ideological base of a community. As a result, communities integrated with a black military presence showed signs of having a positive impact on the minds of many white Americans. Nevertheless, by 1992 more than 70 percent of white Americans across the nation were willing to accept greater levels of integration in neighborhoods with blacks. ${ }^{31}$

\footnotetext{
${ }^{30}$ Ibid, 35.

${ }^{31}$ Ibid, 28.
} 
Table 1

Metropolitan Areas with Greatest and Least Black-White Residential Segregation; 1980 and 1990

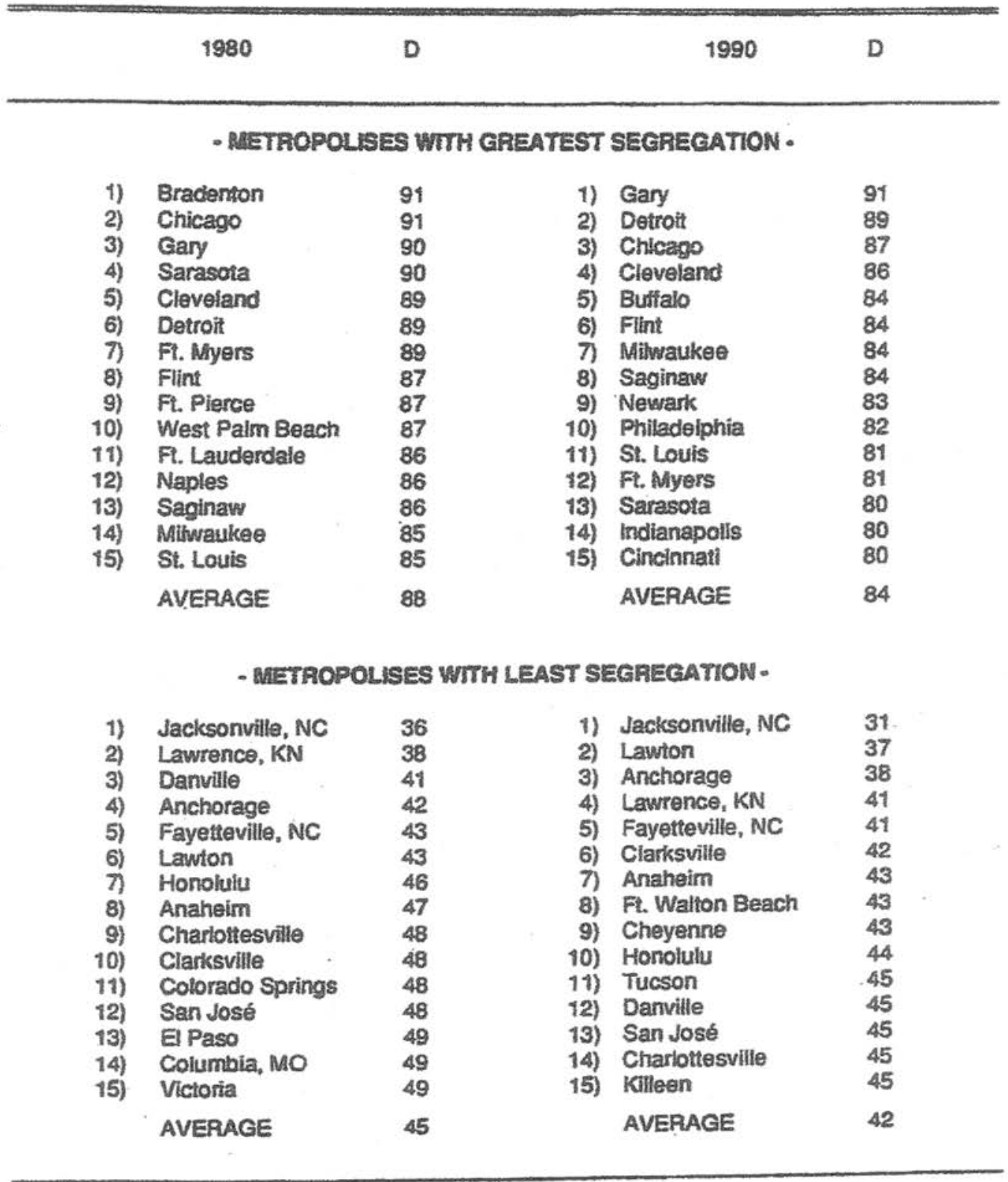

SOURCE: U. S. Bureau of the Census, U.S. Metropolitan Areas, 1980 and 1990. These Indexes are based on block group data and pertain to persons reporting white or black as their race. 
The change in American attitude became more evident in the early 1970s when President Nixon established the military's All-Volunteer Force on July 1, 1973. It was starting to become obvious within individuals and groups that American ideology opposing equality was eroding inside all branches of the military. Education and race patterns of the AVF were not being tracked by the Defense Manpower Commission until $1975 .{ }^{32}$ While some historians might argue that the change was in no way trending for black equality in the military, the facts prove otherwise. Despite the many reasons for establishing the AVF, the military changed from within.

Over time the career opportunities in the military opened up for African Americans. By 1975 career fields opened up significantly for black women rising above 70 percent in the Marine Corps, 80 percent in the Navy, 94 percent in the Army, and 97 percent of Air Force.$^{33}$ In addition, black women represented 16 percent of all women serving in the military in 1975 as compared to 9 percent in $1966 .{ }^{34}$ When examining the Army, Air Force, Coast Guard, Navy and Marine Corps, the percentage of black women serving almost doubled from 1966 to 1975. In 1975, legislation was passed by the House and Senate that allowed black women to attend all of the service academies. ${ }^{35}$ In October 1975, when President Gerald Ford signed Public Law 94-106 (Title VIII), it stated that the service

\footnotetext{
${ }^{32}$ Bernard Rostker, I Want You: The Evolution of the All-Volunteer Force (Santa Monica: Rand Corporation, 2006), 323.

${ }^{33}$ Manuel D. Plotkin, The social and economic status of the Black population in the United States: An historical view, 1790-1978 (Washington, D.C: United Stated Bureau of the Census, 1979, 324. ${ }^{34} \mathrm{Ibid}, 160$, table 115.

${ }^{35}$ James E. Parco and David A. Levy, Attitudes Aren't Free: Thinking Deeply About Diversity in the U.S. Armed Forces (Alabama: Air University Press, 2010), 305.
} 
academies would ensure all women received equal treatment regardless of race, gender or religion. $^{36}$

With the absence of equality for blacks in other American institutions within society, the military became the first place that African Americans received a fair opportunity. In the 1970 s, African Americans began to obtain important leadership positions in the military. One example of such equality was evident in 1975 with Rev. Alice Henderson serving as the first African American woman chaplain in the Army. ${ }^{37}$ She was accorded respect as all other military officers, even receiving her own jeep. ${ }^{38}$ Such respect was displayed in the form of military salutes from enlisted soldiers and junior officers. The impact of black service women was a reflection of the equality granted to their male counterparts.

Despite how long it took African Americans to overcome the criticism of their inability to lead in the military, blacks continued to climb the ladder of success. The opinions of blacks had changed in the White House in the late 1980s. President Ronald Reagan took Lieutenant General Colin Powell as his National Security Advisor from 1987-1989. In 1989, Army General Colin Powell (Figure 1.1) became the highest ranking African-American officer in the armed forces when he became the 12th chairman of the Joint Chiefs of Staff in 1989. The integral role Colin Powell played in the planning and execution of the first Persian Gulf War, under President George H.W. Bush, illustrates the empowerment and

\footnotetext{
${ }^{36}$ Ana M. Martinez Aleman and Kristen A. Renn, Women in Higher Education: An Encyclopedia (Colorodo: Library of Congress, 2002), 49.

${ }^{37}$ Johnson, John H. ed., "AME minister, Rev. Alice M. Henderson, blazes trail for women clerics," Ebony, Vol. 30, No.12, October, 1975, 44-45.

${ }^{38}$ Ibid, 46.
} 
trust placed upon him as a leader. Colin Powell, now a retired four-star general in the United States Army, was an African American with a remarkable story and transcendent military career.

Figure 1.1

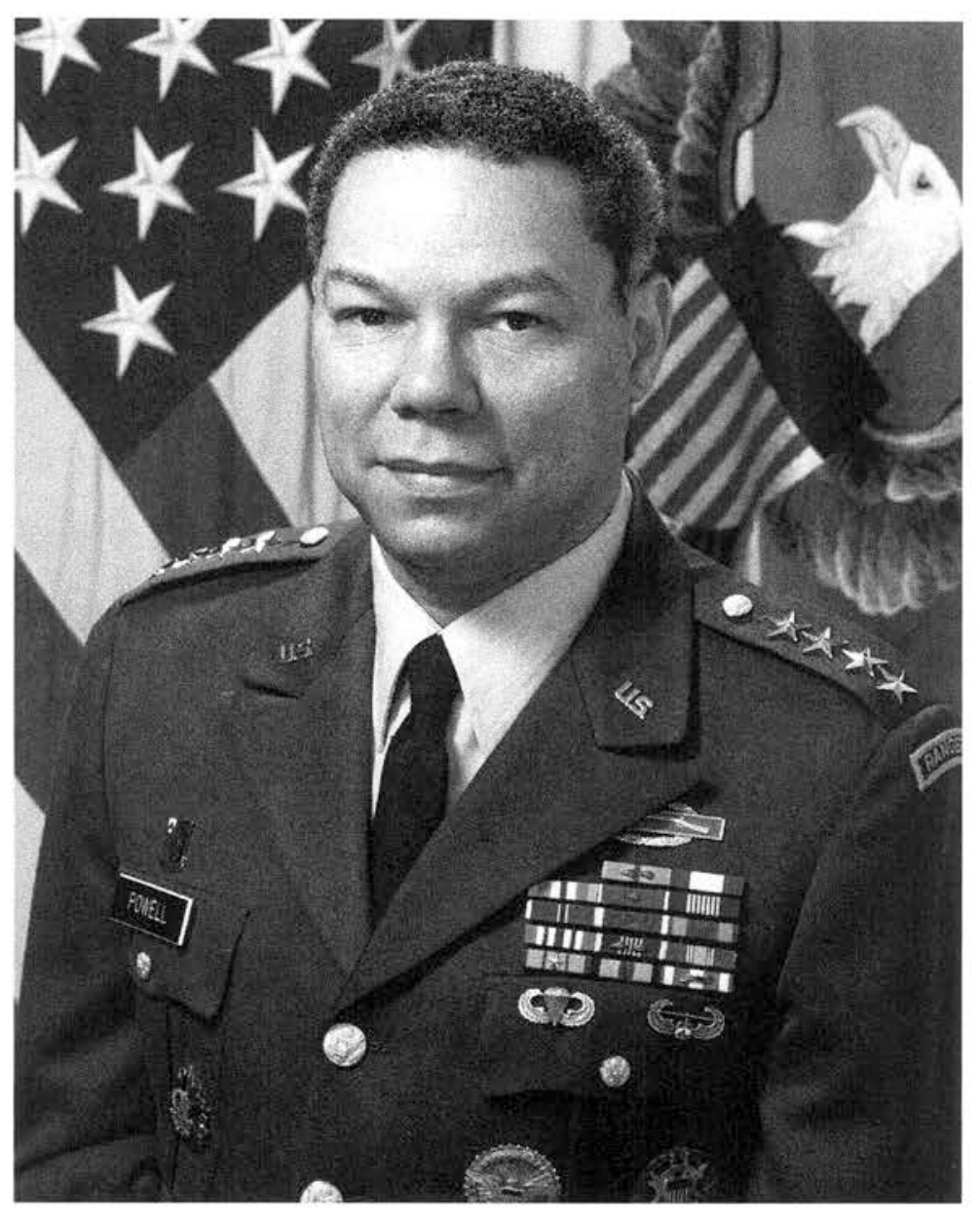

Above: Army Gen. Colin Powell, in his official chairman of the Joint Chiefs of Staff photo taken at the Pentagon in 1989. Taken from John C. Cothran, A Search for African American life, Achievement and Culture, 255. 
Since the 1990s, African American service members have been serving at higher representation in the armed forces than ever before. The propensity to serve in the military among African American men and women was much higher serving in an All-Volunteer Force than during the draft, according to research conducted by Jerald Bachman. ${ }^{39}$ When examining the statistics of AfricanAmerican service members, research shows how a key change in the ability to experience continued success in the military was aided by war. A Department of Defense study revealed that blacks maintained a share of all military personnel right above twenty percent in the armed forces during the 1990s. ${ }^{40}$

With conflicts such as the Persian Gulf War (Desert Storm) and the Cold War ending in 1991, so did a conflict in ideologies. The Cold War conflict between capitalism and communism left behind an even greater desire in Americans to examine freedom and equality at home within American democracy. ${ }^{41}$ The Persian Gulf War sparked change within the armed forces. Such change led to self-reflection within society that led to transparent alterations within the military. Those changes proved to advance the quality of life for African Americans with prosperity during the 1990s.

In 1991, the U.S. Congress rescinded the combat exclusion law banning women from aviation combat. This turned out to be a very significant step that improved the professional opportunities for black women in the military. Prior to

\footnotetext{
39 Jerald G. Bachman, "Trends in Military Propensity and the Propensity-Enlistment Relationship," Occasional Paper 40 (Ann Arbor, MI: Monitoring the Future, 1997).

${ }^{40}$ Department of Defense, Population Representation in the Military Services, FY2002 (2004), tables D-17, D-27.

${ }^{41}$ William Dudley, The Cold War: Opposing View Points (San Diego: Greenburg Press Inc., 1992).
} 
1991, the combat aviation exclusion laws banned women in the Navy, Marine Corps, Army and Air Force from being assigned to aviation squadrons with combat missions. The shifting mindset of American politicians for improving equality in the armed forces was never more evident as when Senator John Warner (R-VA) said during a debate on the Senate floor, "We are dealing with one of the most important moments in the history of the armed forces of the United States. ${ }^{, 42}$ This was a significant step that created fairness for all military women, including African Americans.

During the 1990s President Bill Clinton was eager to recognize blacks as American patriots by bringing justice to an unfair military system. For example, President Clinton pardoned Freddie Meeks, who was one of the last remaining survivors of the so-called "Port Chicago-50" for his wartime mutiny conviction in 1999. ${ }^{43}$ President Clinton's administration believed that the armed forces should be comprised of an accurate representation of the nation it fights to defend, according to Department of Defense Advisor Dr. David Armor. ${ }^{44}$ Together, many white Americans, including military officers that commanded African Americans continued to be very outspoken in their support for African-American equality in the armed forces.

When reflecting on how the Medal of Honor $(\mathrm{MOH})$ was awarded during WWII, history has shown that initially no blacks were recipients of such an

\footnotetext{
${ }^{42}$ U.S. Congress. Senate. National Defense Authorization Act for Fiscal Years 1992 and 1993: Hearings before the United States Senate. 102nd Cong., 1st sess., 137: 11423, July 31, 1991. ${ }^{43}$ Bill Clinton, Pardons and Commutations, The United States Department of Justice, 1999, http://www.justice.gov/pardon/clinton-pardons

${ }^{44}$ David J. Armor and Curtis L. Gilroy, "Changing Minority Representation in the U.S. Military," Armed Forces and Society, Vol. 36, No.2, January 2010, 223-246.
} 
award. Since its first presentation in 1863 , the $\mathrm{MOH}$ has always been recognized as the nation's most prestigious honor for military valor. More than 3, 477 Medals of Honor have been awarded..$^{45}$ A study conducted by Shaw University in 1993, revealed that within the Army "there was disparity in the way the Medal of Honor recipients were selected. ${ }^{46}$ The findings revealed by Shaw University revealed that several African American soldiers should have been awarded the Medal of Honor during WWII. Whether accidentally or intentionally, "some military personnel records were destroyed for these individuals in a 1973 fire at the National Personnel Records Center. ${ }^{47}$ It took an immense amount of research in the late 1990s to finally correct this injustice.

For the first time during the 1990s, black service members in the armed forces were being honored for their service publicly. The public ceremonies throughout the 1990s recognized a job well done by the men and women who served their country. Despite the long wait, on January 13, 1997 President Clinton awarded the Medal of Honor to seven African-American veterans of WWII. The $\mathrm{MOH}$ recipients were First Lieutenant Vernon J. Baker, Staff Sergeant Edward A. Carter, Jr., First Lieutenant John R. Fox, Private First Class Willy F. James, Jr., Staff Sergeant Ruben Rivers, Private George Watson, and Captain Charles L. Thomas for their exceptional valor during WWII. Unfortunately, the only WWII

\footnotetext{
${ }^{45}$ Anne Leland, Medal of Honor Recipients: 1979-2013, CRS Report for Congress, 113-1 sess., May $16,2013,1$.

${ }^{46}$ United States Army Center of Military History, "African American WWII MOH Recipients," August 13, 2013. http://www.history.army.mil/moh/mohb.html

${ }^{47}$ Ibid.
} 
veteran alive to receive his award was Vernon Baker, while the other six soldiers were awarded their medals posthumously to family members. ${ }^{48}$

Another African-American Medal of Honor Recipient recognized by President Clinton was Corporal Andrew Jackson Smith. On January 16, 2001, Corporal Smith was the last African American to be awarded the $\mathrm{MOH}$ for military actions during the Civil War. Although it took over 137 years to properly honor his bravery, the award was fitting. The citation read:

Corporal Andrew Jackson Smith of Clinton, Illinois, as a member of the 55th Massachusetts Voluntary Infantry, distinguished himself on 30 November, 1864, by saving his regimental colors after the color- bearer was killed during a bloody charge in the battle of Honey Hill, South Carolina. Although half of the officers and a third of the enlisted men engaged in the fight were killed or wounded, Corporal Smith continued to expose himself to enemy fire by carrying the colors throughout the battle. Through his actions, the regimental colors of the 55th Infantry Regiment were not lost to the enemy. ${ }^{49}$

Those words told the story of a forgotten soldier who happened to be an extraordinary soldier. This ceremony was another example of how white Americans were finally acknowledging that many of the nation's heroes were African Americans. Furthermore, America would continue to right the wrongs of military recognition by investigating the awards process for other conflicts.

\footnotetext{
${ }^{48}$ United States Army Center of Military History, "African American WWII MOH Recipients," August 13, 2013. http://www.history.army.mil/moh/mohb.html

${ }^{49}$ Leon Harris, CNN Anchor, President Clinton Awards Medals of Honor to Corporal Andrew Jackson Smith and President Teddy Roosevelt, transcript, January 16, 2001. http://transcripts.cnn.com/TRANSCRIPTS/0101/16/se.04.html
} 
Throughout the twenty-first century Congress continued improving equal opportunity for African-American service members. Even though war records were sealed after WWII, the Korean War and the Vietnam War, Congress called for a review of American veteran's war records through the National Defense Authorization Act of $2002 .{ }^{50}$ While the review was initially to ensure that JewishAmerican and Hispanic-American veterans were not denied the Medal of Honor because of race, the review was amended in 2002 to include African-American veterans. This act was more than a temporary solution. Congress, through legislation, continued pushing to eradicate all obstacles in the way of equality for blacks in the military that still remained.

In 2015, President Barack Obama, like other Presidents, was able to utilize the power of the Presidency to award the Medal of Honor to a heroic AfricanAmerican soldier. For example, Sergeant $1^{\text {st }}$ Class (retired) Melvin Morris (Figure 1.2) was a living veteran honored during a White House Ceremony. ${ }^{51}$ Reflecting on a twelve year Pentagon review, which commenced in 2002, the President addressed military discrimination of the past stating:

No nation is perfect the President said at today's ceremony. But here in America, we confront our imperfections and face a sometimes painful past, including the truth that some of these soldiers fought and died for a country that did not always see them as equal. ${ }^{52}$

\footnotetext{
${ }^{50}$ The Library of Congress, National Defense Authorization Act for Fiscal Year 2002, 107th Cong., 2002, S.1438, Sec. 552. http://thomas.loc.gov/cgi-bin/query/z?c107:S.1438.ENR (accessed January 24, 2016).

${ }^{51}$ David Hudson, "President Obama Awards the Medal of Honor to 24 Army Veterans," the White House, March 18, 2014. https://www.whitehouse.gov/blog/2014/03/18/president-obamaawards-medal-honor-24-army-veterans

${ }^{52}$ Ibid.
} 
The spoken equality in the above passage was never more evident than when President Obama awarded the Medal of Honor to Sergeant. $1^{\text {st }}$ Class Melvin Morris for his bravery and heroic valor during the Vietnam War.

Figure 1.2

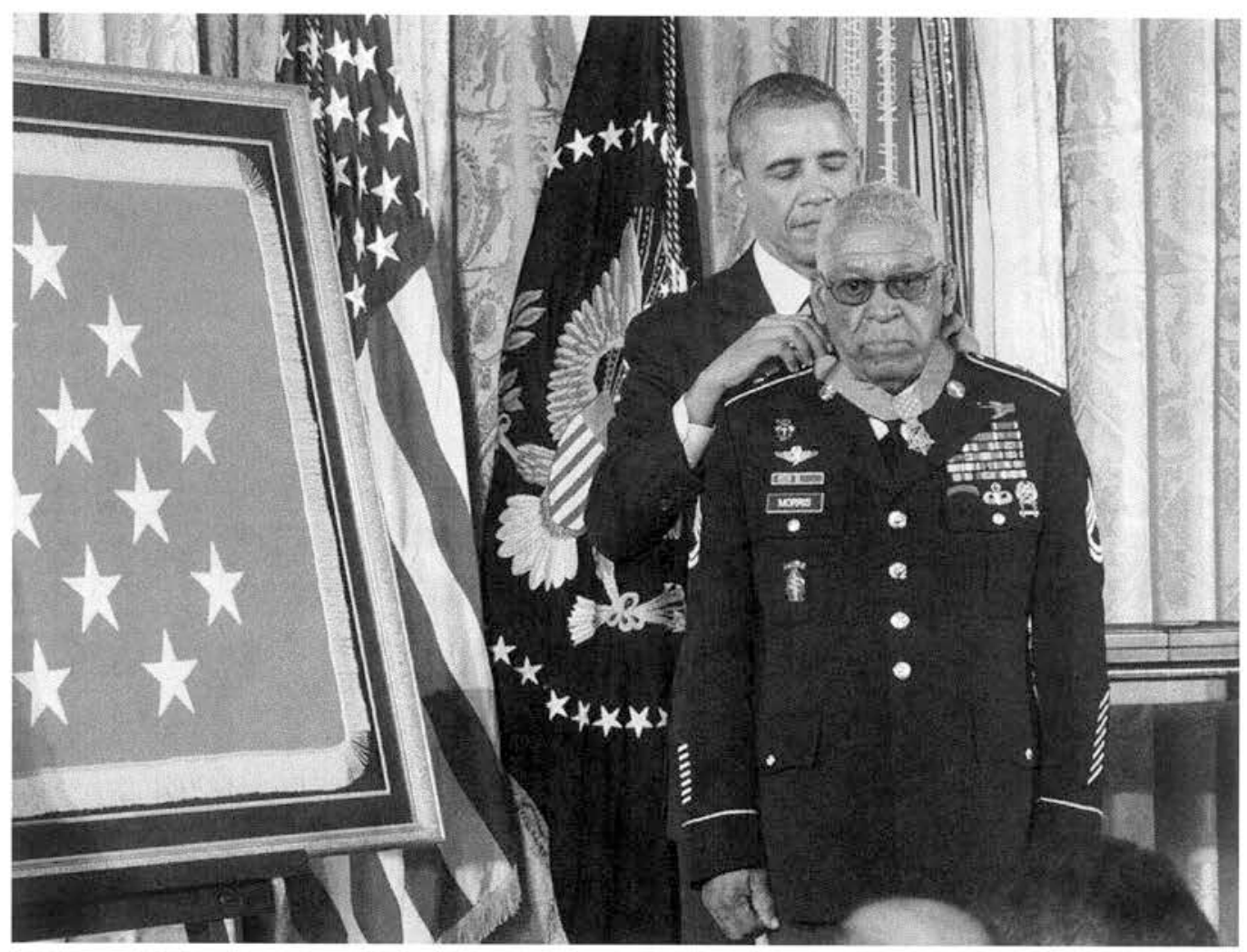

President Barack Obama awarded Sergeant 1st Class (retired) Melvin Morris the Medal of Honor during a ceremony in the East Room of the White House in Washington, March 18, 2015. Taken from the Army Times, accessed January 13, 2016. (www.army.mil) 
Prior to 2015, Army Corporal Freddie Stowers was the only AfricanAmerican recipient of the Medal of Honor for service during World War I. ${ }^{53}$ No longer able to deny Sergeant Henry Johnson's heroic actions during WWI, on June 2, 2015 President Obama awarded the Medal of Honor to Sergeant Henry Johnson (Figure 1.3) posthumously. ${ }^{54}$ Even before receiving the $\mathrm{MOH}$, Sergeant Johnson was posthumously awarded the Purple Heart in 1996.These actions represented the correction of an injustice almost 100 years old, which was acknowledged by President Obama who stated that "No one who serves our country should ever be forgotten, we are a nation, a people, who remember our heroes." ${ }^{55}$ President Obama, just like on March 18, 2015, reminded the American people about matters of race explaining that:

America can't change what happened to Henry Johnson, We can't change what happened to too many soldiers like him, who went uncelebrated because our nation judged them by the color of their skin and not the content of their character. But we can do our best to make it right." 56

In other words the President says that in order for the U.S. to achieve progress the nation must focus on the present and not the past. Although discrimination against blacks was acceptable in the past, it will never be tolerated again.

\footnotetext{
${ }^{53}$ Leland, Medal of Honor Recipients, 3.

${ }^{54}$ Michelle Tan, "WWI heroes Johnson, Shemin Receive Medal of Honor," The Army Times, June 2, 2015. (http://www.armytimes.com)

${ }^{55}$ Ibid.

${ }^{56} \mathrm{Ibid}$.
} 


\section{Figure 1.3}

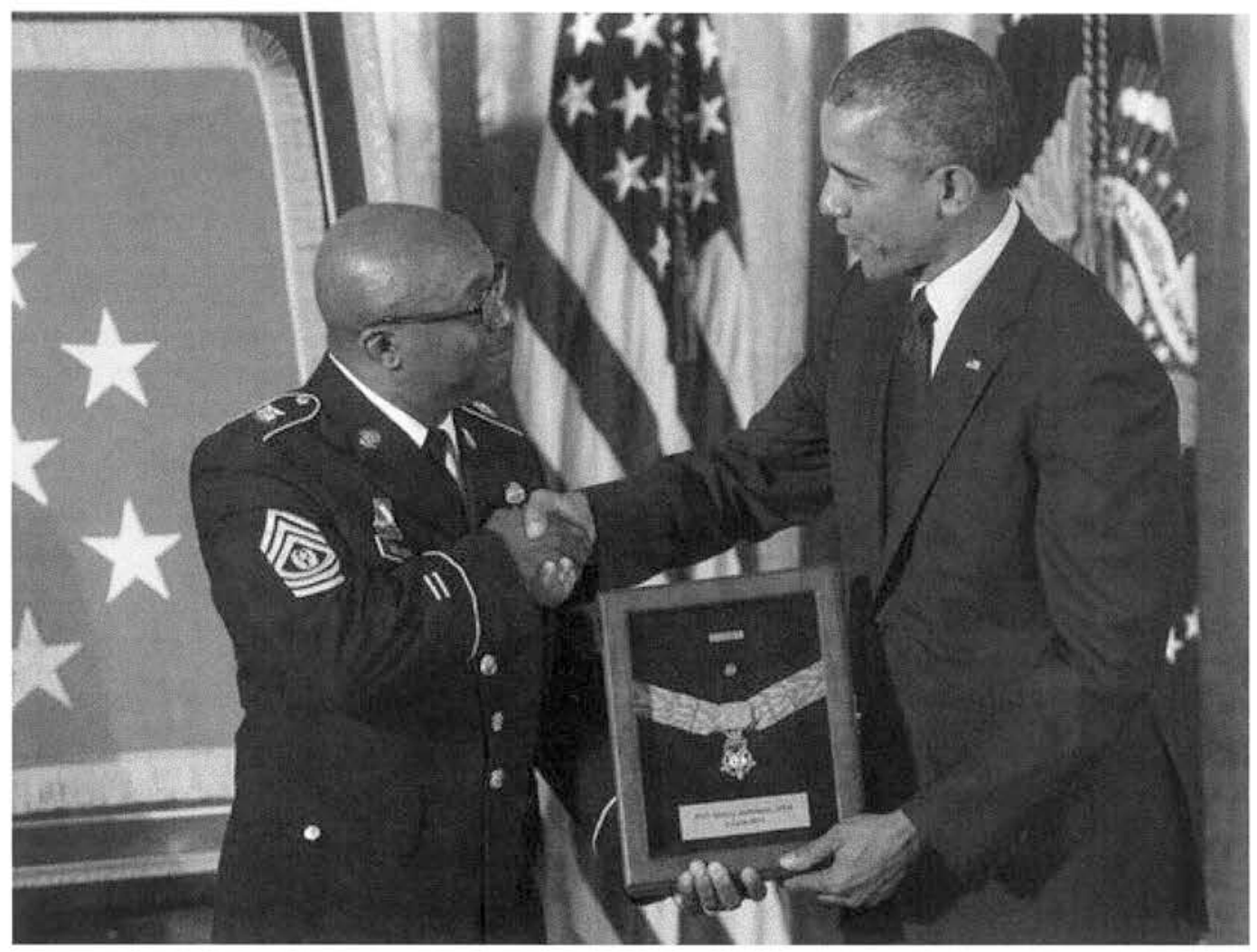

President Obama, right, presents the Medal of Honor to Command Sergeant Major Louis Wilson of the New York National Guard, on June 2 at the White House. Wilson accepted on behalf of the late Army Sergeant Henry Johnson for actions while serving in France during World War I. Taken from Army Times, accessed January 13, 2016.

(http://www.armytimes.com/story/military/careers/army/2015/06/02/world-war-i-heroes-sheminjohnson-medal-of-honor/28344347/) 
In the twenty-first century there is no denying that progress towards equality for blacks in the military continued through the political system. The military's improvements in equality for blacks, which were apparent in the late twentieth century, crossed over to the twenty-first century as well. As the twentyfirst century began, Secretary of Defense, William S. Cohen stated:

On countless occasions I've been asked by foreign leaders, "How can our military be more like America's?" I'll repeat here today what I've said time and time again. It's not our training, although our training is the most rigorous in the world. It's not our technology, although ours is the most advanced in the world. And it's not our tactics, although ours is the most revolutionary in the world. We have the finest military on Earth because we have the finest people on Earth, because we recruit and we retain the best that America has to offer." 57

The above quotation seems to highlight the idea that American men and women were no longer viewed based on color but rather of their humanity. It also states that human beings serving in the military were finally viewed as equal by the American nation. Although it can be argued by some historians that racism and inequality was still present among leaders in the military during the twenty-first century, strides towards equality for African Americans in the military continued.

A key event that symbolized unity of all military personnel regardless of race occurred on September 11,2001. The terrorist attacks on the World Trade Centers were an attack against all Americans. In fact, blacks, whites, Hispanics, Jews, and various other ethnicities were killed during the terrorist attacks. 9/11 marked a significant turning point in American society. Arguably the most

\footnotetext{
${ }^{57}$ William S. Cohen, Farewell to U.S. Armed Forces (Washington, DC: U.S. Department of Defense, 2001.)
} 
unifying expression depicting a true sense of color blindness within the American military came from the Commander-in Chief, President George W. Bush who stated:

This is a day when all Americans from every walk of life unite in our resolve for justice and peace. America has stood down enemies before, and we will do so this time. None of us will ever forget this day. Yet, we go forward to defend freedom and all that is good and just in our world. Our military is powerful, and it's prepared. ${ }^{58}$

The above statement by President Bush indicated just how much the American military leadership had shifted beyond race. Captain Eric Mitchell, a twenty-seven-year old Air Force Captain, recalled having his first assignment as a flight commander after the horror of $9 / 11 .{ }^{59}$ In 2001 , Captain Mitchell was one of the many African-American pilots who flew his plane over Afghanistan to attack Al-Qaeda. This is just an example of the demands placed on the U.S. military as a result of $9 / 11$ that created an opportunity not just proving the capabilities of black men but also highlighting those of black women to "taking the training, passing it successfully, and demonstrating that the particular person, man or woman, could do the job." 60

When thinking about Prisoners of War (POW) during American conflicts, civilians and military alike viewed them typically as men.

\footnotetext{
${ }^{58}$ George W. Bush, "Address to the Nation on the Terrorist Attacks," September 11, 2001. Online by Gerhard Peters and John T. Woolley, The American Presidency Project. http://www.presidency.ucsb.edu/ws/?pid=58057

${ }^{59}$ Ron Tarver and Yvonne Latty, We Were There: Voices of African American Veterans, from World War II to the War in Iraq (New York: HarperCollins Publishers, Inc., 2004),171.

${ }^{60}$ U.S. Congress, House, Hearings on HR 9832, Subcommittee No. 2 of the House Committee on Armed Services (U.S Government Printing Office, 1975), 100.
} 
However, in 2003 during Operation Iraqi Freedom, two women became POW's. ${ }^{61}$ Of the two women POW's, PFC Jessica Lynch was white and Specialist Shoshana Johnson was black. ${ }^{62}$ Just as PFC Jessica Lynch was praised by Americans for her bravery and patriotism on national television, so was Specialist Johnson. Specialist Johnson, who was wounded and captured on March 23, 2003, was a prisoner for 22 days in Nasiriyah. ${ }^{63}$ Shoshana Johnson became the first African-American woman POW during any conflict in American history ${ }^{64}$ Although suffering such a tragic experience while serving her country in the U.S. Army, Specialist Johnson's remarkable service was not forgotten. In fact, Specialist Johnson received numerous awards for her valor after she returned to the United States, including Prisoner of War medals, Bronze Star, and the Purple Heart. ${ }^{65}$

In the twenty-first century some of the most senior leaders in the Department of Defense (DOD) took key steps in ensuring blacks not only served in the enlisted ranks but also as military officers. In the Navy it was Chief of Naval Operation (CNO) Admiral Gary Roughead who took responsibility for blacks receiving fair representation as officers in the Navy. CNO Admiral Gary Roughead, in his own words stated:

\footnotetext{
${ }^{61}$ Jessie Carnie Smith, Black First: 4,000 Ground-Breaking and Pioneering Historical Events (Michigan: Visible Ink Press, $3^{\text {rd }}$ edition, 2013), 451.

${ }^{62}$ Ibid.

${ }^{63}$ "Shoshana Johnson," Simon \& Schuster, http://authors.simonandschuster.com/shoshanajohnson/46047911 (accessed January 18, 2016.)

${ }^{64}$ Ibid.

${ }^{65}$ Shoshana Johnson, I'm Still Standing: From Captive U.S. Soldier to Free Citizen, My Journey Home (New York: Simon \& Schuster, Inc., 2010.)
} 
If you look at the Navy in its entirety, it's a representative mix of America's society. But if you look at the leadership, it tends to be very white male. And that is not the direction where the country is going and nor is it from that non-diverse group that you get, in my mind, the best solutions to problems....It's from diversity that I think you get many different perspectives, different ideas, you get different experiences and that gives you a richness of solutions that you otherwise wouldn't have...

We are beginning to see things that are moving in the right direction. For example, at our Naval Academy, we are bringing in the most diverse group in its history. And that is a function of not offering any type of special programs or compromising on any standards that have existed at the Naval Academy, but rather on a commitment to getting out and talking to people and making young people aware of the opportunities that exist in the Navy. ${ }^{66}$

From the mid-to-late 2000s, other leaders in the Army, Air Force, Coast Guard and Marine Corps shared the opinion of Admiral Gary Roughead. Together senior leaders in the various branches of the military aggressively ensured that blacks and other minorities maintained the opportunity to serve not just in the enlisted ranks, but as officers.

Indeed, since the beginning of the AVF only three percent of the officer corps was African American. ${ }^{67}$ Yet by 2002, black officers comprised about nine percent. ${ }^{68}$ Over a decade later in 2013, the number of black officers rose to ten percent. ${ }^{69}$ As the early twenty-first century continued to reflect military progress for black men, black women began

\footnotetext{
${ }^{66}$ Lindsay Wise, "Sunday Conversation: Navy Chief Says It's Time for a Change, Roughead Sees Need for More Diversity in Leadership Roles," Houston Chronicle, July 25, 2009.

${ }^{67}$ David R. Segal and Mady Wechsler Segal, "America's Military Population," Population Bulletin, Vol. 59, No.4, December 2004, 19-20.

${ }^{68}$ Ibid.

${ }^{69}$ Elizabeth Culhane, "Annual Demographic Profile of the Department of Defense and United States Coast Guard Fiscal Year 2013," Defense Equal Opportunity Management Institute, Demographic Report No. 01-14, 7.
} 
to follow suit as well. By 2013 black women officers in the military were serving at 18.5 percent. ${ }^{70}$ The total number of black women in the Army, Navy, Marine Corps, Air Force and Coast Guard in 2013 was larger than any other minority group. Black women officers in the military nearly tripled in comparison to Asian and Hispanic women by $2013 .^{71}$

When Barack Obama was elected as the President of the United States on January 20, 2008, he became the first African-American Commander-in-Chief. Needless to say, there has never been a black President or Vice President of the United States. This was a major accomplishment for African Americans, especially in the military. President Obama as Commander-in-Chief was officially at the top of the military chain of command. President Obama's election is a reflection that many Americans finally view the nation as a post-segregated/racial society with equal opportunity for all.

As members of the U.S. military, African Americans have had indecisive feelings about defending America's freedoms for quite a long time during an era of discrimination and segregation. Many of those feelings were due to unfair treatment, and a lack of public recognition. However, by 2015 blacks within the enlisted and officer ranks were no longer subjected to discrimination or the belief of inferiority that once prevented them from leadership roles and responsibility. Furthermore, what has become evident from 1975 to 2015 is the shift in attitude within

\footnotetext{
${ }^{70}$ Ibid, 13

${ }^{71}$ Ibid.
} 
the military and society as a direct reflection of blacks and whites working together constantly to improve establishing equality. 


\section{Chapter Two}

The Triumph of Legislation

African-American equality in the military continued to flourish after 1975 with the help of the Civil Rights legislation of the 1960s. While focusing on the period after 1975, this chapter will examine how African-American life in the military has continued to improve in each branch of the armed forces resulting from changes in legislation and military directives. How did the Civil Rights legislation during the 1960 s change military regulations and improve AfricanAmerican equality in military housing? Furthermore, what did the changes in Department of Defense Directives/Instructions do to ensure that blacks would be treated equally in the military? Answers to the above questions are included in this chapter to illustrate how the military ended segregation within its ranks..

By 1975, African Americans began to witness how barriers in place within the military, as a result of race, continued to fall. Of course, changes to laws that improved the lives of blacks in the military are indeed intertwined with the Civil Rights Acts of the 1960s. Where other laws pertaining to the equality of blacks may have failed, legislation like the Civil Rights Act of 1964 did not. President Lyndon B. Johnson made the Civil Rights Act of 1964 one of his top priorities after he became President Kennedy's successor in $1963 .{ }^{1}$ Furthermore, it was President Johnson who said "With the enactment of Title VII, the Civil Rights Act

\footnotetext{
${ }^{1}$ The American Mosaic: The African American Experience, "Civil Rights Act of 1964," http://0-africanamerican2.abcclio.com.sally.sandiego.edu (accessed January 19, 2016).
} 
of 1964 took a major step toward giving minority Americans opportunities to compete for jobs that had never before been open to them."

Additionally, President Johnson passed the Civil Rights Act of 1968, which included the following:

a prohibition against discrimination when renting or selling lodging, and criminal punishment for stopping someone from performing activities considered part of one's civil rights such as voting, going to school, etc."”

This meant that blacks were now promised the rights they fought so desperately for in the areas of public recreation, housing, education and other areas of accommodations within the military.

This example of promoting African-American equality was displayed in the Department of Defense Instruction governing Morale, Welfare and Recreation (MWR) services. The MWR Program was revised in the late twentieth century to correct the lingering restrictions on military bases in the 1950s and 1960s of discrimination towards black. It cannot be overlooked that although the military was desegregated by President Truman, blacks did not benefit right away. What became obvious in all branches of the military was that blacks complained that they were denied military privileges and recreational facilities on a regular basis. ${ }^{4}$ Many changes in MWR services were a direct result of military club scandals that

\footnotetext{
${ }^{2}$ Ibid.

${ }^{3}$ United States Department of the Interior, "The African American Legacy and the Challenges of the 21st Century," Office of Civil Rights. https://www.doi.gov/pmb/eeo/AAHM\#main-content (accessed January 19, 2016).

${ }^{4}$ Gail Buckley and David Halberstam, American Patriots: The Story of Blacks in The Military from the Revolution to Desert Storm (New York: Random House, 2002.)
} 
were investigated by Congress in $1968 .{ }^{5}$ In 1969 , it was decided by the Supreme Court that discrimination in public accommodations, including recreation areas was against the law. ${ }^{6}$ Although it can be argued by some that those changes did not come quickly enough, they were aided by the Civil Rights Movement. Research shows that by 1995 , U.S. Military MWR services officially applied to all public on and off base accommodations including gyms, libraries, child care, family programs, equipment rentals, recreational clubs and recreational lodging. ${ }^{7}$

Unfortunately, not all American employers were required to follow the Civil Rights Act of 1964 and 1968 until the early 1970s. In 1972 Congress passed the Equal Employment Opportunity Act thereby strengthening Title VII of the Civil Rights Act of 1964 and making it illegal for all employers to discriminate against any individual because of race, color, religion, sex, or national origin. ${ }^{8}$ With help from senior leadership in both the military and civilian sectors, blacks continued fighting for the rights they were promised. More than ever, military leaders continued to publicly express their dissatisfaction regarding the problems that African Americans continued to face.

\footnotetext{
5 "History of Military Recreation Programs," Military One Source, http://militaryonesource. mil/mwr/overview?content id=266802 (accessed February 1, 2016.)

"United States Department of the Interior, "The African American Legacy and the Challenges of the 21st Century," Office of Civil Rights. https://www.doi.gov/pmb/eeo/AAHM\#main-content (accessed February 1, 2016).

${ }^{7}$ U.S. Department of Defense, Programs for Military Morale, Welfare, and Recreation (MWR), DODI 1015.10, November 3, 1995, 28-29.

${ }^{8}$ The American Mosaic: The African American Experience.
} 
The Armed Forces took a key step towards equal justice by establishing a Task Force for the Administration of Military Justice in $1972 .{ }^{9}$ Deputy Secretary of Defense David Packard acknowledged that "The efforts of the task force, chaired by then Air Force Colonel Lucius Theus, who eventually retired as a Major General in the Air Force resulted in the publication of Department of Defense Directive 1322.11." ${ }^{, 10}$ What this Task Force discovered was that the armed forces needed to find more ways to eliminate racial discrimination throughout the military. As a result, by 1975 the Department of Defense Race Relations Institute (DRRI) appeared. When the DRRI established the Race Relations Education Program, it worked to improve military equality for all American service members.

While there are some Americans who would still argue that African Americans still do not have equality in the military in 2015 , there is no denying that many obstacles and barriers to equality have been removed. In fact, the military continued making strides in establishing equal opportunity for African Americans with major developments by 1975 . Those developments contributed to changes in military policies, programs and practices inside the military. Changes to Department of Defense Directives (DoDD) and Department of Defense Instructions (DoDI) began referencing civilian legislation that guaranteed equality of blacks in the civilian sector with hopes of doing the same in the military.

\footnotetext{
${ }^{9}$ United States, Task Force on the Administration of Military Justice in the Armed Forces (Washington: Dept. of Defense, U.S. Government Printing Office, 1972).

${ }^{10}$ Bryan Ripple, "DEOMI Marks $40^{\text {th }}$ Year of Equity Training and Research Today," Defense Equal Management Opportunity Institute, (June 24, 2011 No. 11-06-18):1-2.
} 
Faced with much needed improvements due to public complaints of discrimination against blacks, the U.S. military continued to modify programs and policies in an effort to enhance the rights of blacks in the military. This led to establishing the Department of Defense Equal Opportunity Program (DoD Directive 1100.15. The DoDD mandated each branch of the military to create and execute plans ensuring all organizations and establishments on and off base guaranteed the equal rights of black servicemembers. ${ }^{11}$

When it came to the inequality of housing, Secretary of Defense William Perry acknowledged that military progress initiated in 1967 had started to decline rapidly saying "To no one's surprise, the task force found that military housing fails to meet the Defense Department's intended goal." ${ }^{12}$ In 1977, with the backing of the Civil Rights Act of 1968, the Department of Defense implemented the Equal Opportunity in Off-Base Housing Instruction (DoDI 1100.16). ${ }^{13}$ The Civil Rights Act of 1968 was also known as the Fair Housing Act. Due to the enormous complaints that the military was no longer enforcing the equal rights of blacks, the DODI allowed the Secretary of Defense to ensure equal housing for all service members:

The Department of Defense intends that Federal fair housing law shall be supported and that DoD personnel shall have equal opportunity for available housing regardless of race, color, religion, sex, age, national origin, handicap, or familial status. ${ }^{14}$

\footnotetext{
${ }^{11}$ DoD Directive 1100.15, "The Department of Defense Equal Opportunity Program," June 3, 1976.

${ }^{12}$ Bernard Roster, I Want You: The Evolution of the All-Volunteer Force (Santa Monica, CA: Rand Corporations, 2006), 668.

${ }^{13}$ DoD Directive 1100.16, "The Department of Defense Equal Opportunity in Off-Base Housing," June 2, 1977, (canceled).

${ }^{14}$ Ibid.
} 
The intent of this policy was to ensure that African Americans were entitled to housing with the same standards as white service members at all times. Once the Secretaries of each branch of the military ensured that African Americans had the full backing of the law, discrimination in living accommodations began to vanish. Of course to ensure that housing standards remained fair for blacks this instruction was updated to reflect the changing conditions and requirements within the military every decade. ${ }^{15}$

In the decades following the 1980s, the number of homes increased all over the United States as the population continued to rise. ${ }^{16}$ This eliminated the DoD housing shortage. With increased housing unit contracts available for military service members, the military could no longer use the housing shortage as an excuse. Even with more housing available many military personnel and their families cited a lack of affordable housing choices. Changes in the 1980s by President Ronald Reagan to remove barriers of affordability so blacks could afford off base housing were addressed:

It was in part to remedy this deficiency that the President's memorandum to the Secretary of Defense of August 17, 1982, authorizing the Fifth Quadrennial Review of Military Compensation (QRMC), sought a coherent and logical statement of the principles and concepts of military compensation. ${ }^{17}$

\footnotetext{
${ }^{15}$ DoD Directive 1100.16, "The Department of Defense Equal Opportunity in Off-Base Housing," August 14, 1989.

${ }^{16}$ Katie E. Parks, Andre T. Carswell and Russell N. James III, "Residential Satisfaction of Military Household in Privatized Apartment Communities," Housing and Society, (November 1, 2009 Vol 36), 97.

${ }^{17}$ Library of Congress, "Military Compensation Background Papers," Sixth Edition, May 2005. http://www.loc.gov/rr/frd/mil-comp.html (accessed January 23, 2016).
} 
President Reagan acknowledged that it was time to give every member of the armed forces the pay they deserved. Although the affordability issue was not solved right away, by 1998 the Basic Allowance for Housing (BAH) formula was established for all military officers. ${ }^{18}$ This granted blacks the same opportunity as whites to live in the off-base housing of their choosing. Enlisted personnel in the Armed Forces were given the same BAH system in 2001. ${ }^{19}$

During the twentieth century there were plenty of complaints made by African Americans that the military pay system in general was unequal. They claimed that white military members received incentive pay for difficult and specialty jobs that blacks did not. Such claims basically appeared to be speculation at best prior to the 1970s. Yet what research did reveal was that the armed forces added several new pay entitlements to the military compensation table after 1970. To grasp a better understanding of those entitlements they are listed below: ${ }^{20}$

Title

Aviation Enlisted Pay

Nuclear Bonuses

Aviation Officer Pay

Career Sea Pay

Chemical Munitions Pay

Dangerous Organisms Exposure Pay

Engineering Career Pay

Flight Pay

Toxic Fuel Pay

Toxic Pesticides Pay

Psychologist Pay

Nurse Anesthetists

Nursing Pay
Initiation Date

1974

1976

1980

1980

1981

1981

1981

1981

1981

1981

1987

1989

1990

\footnotetext{
${ }^{18}$ Ibid, V.

${ }^{19}$ Ibid.

${ }^{20}$ Ibid.
} 
Changes in the "Pay and Allowance Summary" above could be argued to be a coincidence or it could be evidence that the Department of Defense was trying to right the wrongs of pay inequality. Regardless, African Americans no longer had to wonder if they would receive the same compensation as white service members when performing the same jobs in the military.

According to additional evidence, the Military Pay Tables from 1970 to 2015 , changed dramatically. ${ }^{21}$ In the early 1970 s the pay charts were open to interpretation of a service member's monthly pay, including entitlements. By the 1980s, although still general and not entirely specific with all special pay, the tables still provided more detail to reduce the possibility of inaccurate pay problems. From 1990 on, military pay charts prevented any ambiguity ensuring that all service members were knowledgeable about their pay, thus receiving what they deserved.

Yet in the twenty-first century, there are still some who have argued that even with the same amount of education, African Americans still earn less than their white peers. ${ }^{22}$ Those arguments are made based on evidence from the U.S. Census Bureau of Labor Statistics stating "a Black man with an associate's degree earns, on average, $\$ 15$ per week less than a white man with only a high-school diploma. ${ }^{, 23}$ Research shows that while one can argue such a point in the civilian sector, such an argument no longer applies to African Americans in the U.S.

\footnotetext{
${ }^{21}$ U.S. Department of Defense, "Defense Finance and Accounting Service (DFAS)" http://www.dfas.mil/militarymembers/payentitlements/military-pay-charts.html ${ }^{22}$ Velma McBride Murry and Na Liu, "Are African Americans Living the Dream 50 Years after Passage of the Civil Rights Act?" The Society Pages, January 21, 2015.

${ }^{23}$ Ibid.
} 
military by 2015. When examining the military pay charts from 2000 to 2015, the amount of specificity included prevents any service member from arguing pay inequality for any enlisted or officer personnel based on race or sex. Equal pay has always been a significant factor in the quality of life for African Americans serving in the military. As the quality of life improved for blacks so did their morale, which increased their military retention.

Interestingly enough, research revealed that from 1974 to 1994 the Department of Defense conducted a study about equal opportunity for blacks in the military that also included recommendations directed at further addressing the discrepancies of inequality in all branches. ${ }^{24}$ This study focused on promotions, discipline, education/training and job opportunities for blacks. Just as the view of blacks in society was improving, so was the perception of blacks in the past. For example, even though Henry Ossian Flipper was the first African American to graduate from West Point in 1877 , his career ended in 1882 due to a racially motived court martial. ${ }^{25}$ In 1978 President Jimmy Carter overturned the conviction of Henry Flipper, essentially granting him an honorable discharge from the Army posthumously. ${ }^{26}$ In any event what was revealing about the study was that even though statistics reflected improvement by 1994 in comparison to

\footnotetext{
${ }^{24}$ U.S. Department of Defense, "Equal Opportunity: DOD Studies on Discrimination in the Military," Letter Report, April 07, 1995, NSIAD-95-103. https://www.gpo.gov/fdsys/pkg/GAOREPORTS-NSIAD-95-103/html/GAOREPORTS-NSIAD-95103.htm (accessed January 23, 2016).

${ }^{25}$ James T. Controvich, African-Americans in Defense of the Nation (Lanham: Scarecrow Press, 2011), 7.

${ }^{26} \mathrm{lbid}$.
} 
1975, some Americans still felt that the military system and its benefits were biased against African Americans. ${ }^{27}$

If there was one form of legislation that was originally biased against African Americans, it was the GI Bill of $1944 .{ }^{28}$ Research shows that the 1944 GI Bill itself was not written to deny blacks the same benefits as whites. In fact, this was supposed to be a key piece of legislation providing all men and women veterans' education, training, and loans for purchasing homes; however, blacks were frequently denied those opportunities because there was no clause forbidding racial discrimination.

Fortunately, Congress passed the Veterans Educational Assistance Act of 1984, which is also known as the Montgomery GI Bill Act of $1984 .^{29}$ This was essentially a revision to the 1944 GI Bill. By 1985, educational opportunities became available to blacks once they signed DD Form 2366 (Montgomery GI Bill) which specified:

By law, the DD Form 2366 (Montgomery GI Bill Act of 1984 (MGIB) must be completed and signed by new recruits within 14 days after entering the Service. DD Form 2366 provides an official record of each Service Member's decision regarding participation in the Montgomery GI Bill (MGIB) program. It is also used to ensure that the member understands his/her Montgomery GI educational entitlements. ${ }^{30}$

\footnotetext{
${ }^{27}$ U.S. Department of Defense, Equal Opportunity.

${ }^{28}$ U.S. Congress. Senate Committee on Finance. Servicemen's Readjustment Act (G.I. Bill) of 1944. 78th Cong., 2nd sess., 1944, S. 1617.

${ }^{29}$ U.S. Congress. Committee of Armed Services and Veterans' Affairs, Veterans Educational Assistance Act of 1984, 98th Cong., 2nd Sess., 1984, S. 691.

${ }^{30}$ DD Form 2366, "Montgomery GI Bill Act of 1984 (MGIB)," Chapter 30, Title 38, U.S. Code.
} 
The passage above in the 1984 G.I. Bill have remained applicable to all members of the Armed Forces beyond 1985.

President George W. Bush took the G.I. Bill rights one step further on June 30, 2008 when he signed the Post 9/11 G.I. Bill into law. ${ }^{31}$ Under this new bill, each veteran is entitled to educational benefits that will cover full tuition and fees up to the cost of the most expensive public university in the veterans' home state; it will also provide a monthly housing allowance and a $\$ 1,000$ annual book stipend. ${ }^{32}$ Under this law blacks no longer have to hope that the VA certifies their eligibility, which is automatically guaranteed under federal law. It would be absurd to argue that African Americans are denied the same educational opportunities as whites in the military by 2015 .

Unfortunately in the early 1970s, African-American women were excluded from several career options that were offered to black men in the military. Some of those exclusions during the early 1970s were with at sea billets in the Navy and Coast Guard. Research shows that the USS Sanctuary experiment, which ended in 1975, paved the way to lift restrictions preventing women from serving at sea by pushing for a solution. ${ }^{33}$ One of the first advocates to publicly address how black women performed at sea was the USS Sanctuary Captain by stating:

\footnotetext{
${ }^{31}$ Post-9/11 Veterans Educational Assistance Act of 2008, Pub. L. No. 110-252, 122 Stat. 2357.

${ }^{32}$ Elizabeth Redden, "A Tale of Two GI Bills," Inside Higher Ed., Oct. 3, 2008, http://www.insidehighered.com/news/2008/10/03/gi (accessed January 25, 2016).

${ }^{33}$ Jeanne Holm, Women in the Military: An Unfinished Revolution ( Novato, CA: Presidio Press, 1982), 329.
} 
Women can perform every shipboard task with equal ease, expertise, and dedication as men do. Significant in this regard was the success of women on general quarter's repair parties, and on general emergency teams, performance on which is considered a good gauge of general naval ability. ${ }^{34}$

What the above statement proved was that it was time for women to serve with men on ships.

After 1975, the Department of Defense worked with Congress to rescind sections 6015 and 8549 of Public Law 94-106, which prevented mixed crews from serving on all ships. ${ }^{35}$ From 1978 and beyond, the Navy and the Coast Guard planned to employ mixed crews thus removing all restrictions for black women. The DoD went even further and also repealed sections 6105 and 8549 of Public Law 94-106 for Air Force personnel as well. ${ }^{36}$ For example, in the Air Force women were no longer prohibited from pilot training and flying combat aircraft. All women, through the power of legislative reform, were now able to use their training just like men.

The Army also opened up its aviation program to black women. This was definitely a step in the right direction for military African-American women. The late 1970s proved that African Americans, were ready for all types of combat missions. In 1979, Second Lieutenant Marcella A. Hayes, graduated from the Army Aviation School, and became the first African-American woman pilot in the Army. She would not be the last in the armed forces.

\footnotetext{
${ }^{34}$ Ibid, 329

${ }^{35}$ Ibid, 331.

${ }^{36}$ Ibid, 338.
} 
Although African-American women were first permitted to enter pilot training in 1976, they were not permitted to enter fighter pilot training until 1993. ${ }^{37}$ Of course, African-American women continued to display their hard work and determination by succeeding to become fighter pilots as well. In 1999 Major Shawna Kimbrell became the first female African-American fighter pilot in the Air Force. ${ }^{38}$ Major Kimbrell explained the significance of her achievement:

It is an important step for progression and although I am not fond of the spotlight I think it is important for people to know that this barrier has been breached. Especially for the African-American community and for women to know what types of opportunities are available to them. ${ }^{39}$

Major Kimbrell confirmed that African Americans only needed the opportunity to prove themselves.

Black women in the military continued making history as so-called "firsts." In 2001, Captain Vernice Armour became the first African-American female Combat Pilot. ${ }^{40}$ Proving just how ready she was after September 11, 2001, Captain Armour deployed in 2003 to Iraq conducting dangerous missions in enemy territory to protect her fellow service members on the ground. ${ }^{41}$ The Marine Corps viewed Captain Armour as a trailblazer in an article written by Lance Corporal Chelsea Flowers who said "her role as the first female African

\footnotetext{
${ }^{37}$ U.S. Air Force, "Air Force Personnel Demographics," Air Force Personnel Center, http://www.afpc.af.mil/library/airforcepersonneldemographics.asp (accessed January 31, 2016). ${ }^{38}$ Senior Airman Justin Weaver, "Meet the Air Force's First Female African-American Fighter Pilot," U.S. Air Force, March 21, 2008. http://www.usafe. af. mil/news/story.asp?id=123091118 ${ }^{39}$ Ibid.

${ }^{40}$ Lance Corporal Chelsea Flowers, "America's First Female African American Combat Pilot," The United States Marine Corps Official Blog, February 10, 2012. http://marines.dodlive.mil/2012/02/10/americas-first-female-african-american-combat-pilot/ ${ }^{41} \mathrm{lbid}$.
} 
American combat pilot most certainly has inspired and will continue to inspire future generations of Marines, African Americans and women to greatness. ${ }^{42}$

Analysis conducted for the armed forces by the RAND Corporation revealed that many of the challenges and concerns for African Americans had been resolved by the early 2000s. In fact, the study revealed that all branches of the military, especially the Army, had become "an organization unmatched in its level of racial integration. It is an institution unmatched in its broad record of black achievement." ${ }^{43}$ Even with equal opportunities for blacks in the 2000s, research shows that every Secretary of Defense conducts annual military reviews annually to ensure that equal treatment is provided for all members of the armed forces.

When examining the U.S. military in the twenty-first century, it has become evident that the rights and privileges designated by the Department of Defense applies to all Americans. Although the DOD by 2015 has begun using the "diversity" word to include all minorities, it does not erase the fact that blacks are included. In 2015 the importance of blacks in the military was again emphasized when the National Military Strategy explained the importance of diversity in the military:

To enhance our warfighting capability, we must attract, develop, and retain the right people at every echelon. Central to this effort is understanding how society is changing. Therefore, the U.S.

\footnotetext{
${ }^{42}$ Ibid.

${ }^{43}$ Bernard Roster, I Want You, 323.
} 
military must be willing to embrace social and cultural change to better identify, cultivate, and reward such talent. ${ }^{44}$

This shows just how much the Department of Defense has continued to advocate for African-American equality in the military by constantly maintaining a commitment to diversity.

If there is one thing that history has revealed, it is that Congress has not stopped fighting to change laws that would improve opportunities for African Americans in the military. Such was illustrated in 2015 in the National Defense Authorization Act for Fiscal Year 2016, which stated:

Diversity contributes to the strength of the Armed Forces.... It is the sense of Congress that the United States should - (1) continue to recognize and promote diversity in the Armed Forces; and (2) honor those from all diverse backgrounds and religious traditions who have made sacrifices in serving the United States through the Armed Forces. $^{45}$

The message reflected in the above passage confirms that Congress and the U.S. military view all service members as a collective entity of equal human beings.

Another historic transformation which improved equality not just for African-American women but all military women occurred in December 2015 when the Department of Defense lifted all military restrictions on the military service of women and allowed them to take

\footnotetext{
${ }^{44}$ Department of Defense, Chairman of the Joint Chiefs of Staff, The National Military Strategy of the United States of America 2015.

${ }^{45}$ Kristy M. Kamarck. Diversity, Inclusion, and Equal Opportunity in the Armed Services: Background and Issues for Congress, CRS Report for Congress, December 23, 2015, 6.
} 
combat jobs. ${ }^{46}$ Secretary of Defense Ash Carter felt that all military

women were free to serve in any military job they qualified for. He said:

They'll be allowed to drive tanks, fire mortars, and lead infantry soldiers into combat. They'll be able to serve as Army Rangers and Green Berets, Navy SEALs, Marine Corps infantry, Air Force parajumpers and everything else that was previously open only to men. ${ }^{47}$

Finally, it appeared that the Department of Defense had ideas and values of a common goal for the fair treatment of African Americans in the military. Furthermore, those ideas became a reality through the significant changes in the Department of Defense Directives/Instructions which were influenced by Civil Rights legislation during the 1960s. In reality, these changes led to a deeper understanding of ways to remove all barriers preventing African-American equality. By examining military promotions, the following chapter will illustrate the empowerment of blacks in ways that contribute to African-American equality in the armed forces.

\footnotetext{
${ }^{46}$ Andrew Tilghman, "All combat jobs open to women in the military," Military Times, December 3, 2015. http://www.militarytimes.com/story/military/pentagon/2015/12/03/carter-tellingmilitary-open-all-combat-jobs-women/76720656/(accessed January 27, 2016).

${ }^{47}$ Ibid.
} 


\section{Chapter Three}

The Empowerment of African Americans

"If there is no struggle, there is no progress"1

Throughout American history, it has been an "uphill battle" for African Americans to be promoted to the highest ranks in the military. This chapter will focus on how much times have changed for African-American progress within all branches of the U.S. military from 1975 to 2015. It will illustrate that although the ranking structure may be imbalanced in numbers, it is, of course, a significant improvement over what prevailed prior to 1975 . Additionally, it will examine the extraordinary careers of blacks in some of the most prestigious and key positions across all military branches. This chapter will also illustrate how the United States military has recognized black heroes in significant ways and show how blacks have been given a greater responsibility for leading and commanding all service members in the military beyond 1975 .

When examining race overall, the Census Bureau shows that the percentage of blacks in the Army had increased from the 10 percent in 1949 to 20 percent in 1975; in the Navy from 4 percent to 8 percent; in the Marine Corps, from 2 percent to 17 percent; and in the Air Force, from 5 percent to 13 percent. $^{2}$

\footnotetext{
${ }^{1}$ Frederick Douglass, "The Significance of Emancipation in the West Indies," in the Frederick Douglass Papers, Volume 3, 1857, ed. John W. Blassingame (New Haven: Yale University Press, 1985), 204.

${ }^{2}$ Manuel D. Plotkin, The social and economic status of the Black population in the United States: An historical view, 1790-1978 (Washington, D.C: United Stated Bureau of the Census, 1979), 160 , table 114.
} 
Black enlisted service members doubled from 7 percent to 16 percent from 1949 to 1975 while black officers increased from 2,000 to $9,000 .{ }^{3}$ By 1975 , the military was on track to improve career opportunities for blacks in all ways.

When examining African-American advancement across all branches of the military, research shows that many blacks promoted after 1975 were still being recognized as so-called "first" of their kind. For example, Lieutenant Donna Davis became the first black woman doctor in the Naval Medical Corps in May 1975. Just one year earlier in October 1974, the U.S. Navy qualified the first African American woman pilot. ${ }^{5}$ This can be attributed to the fact that in the mid1970s, officer promotions for women and men were still segregated in the military. ${ }^{6}$ However, when Congress passed the Defense Officer Personnel Management Act (DOPMA) in December 1980, matters changed. ${ }^{7}$ By 1981, officer promotions in all branches of the military were integrated for black women and men. For the first time African-American men and women were being evaluated with their white counterparts for officer promotions.

During the final twenty-five years of the twentieth century, there were many recognizable changes in all branches of the U.S. military. In 1971, the first black Rear Admiral in the U.S. Navy was Samuel Gravely (Figure 3.1). He was

\footnotetext{
${ }^{3}$ Ibid, 159, table 113.

${ }^{4}$ Buffalo Soldiers Research Museum, http://www.buffalosoldiersresearchmuseum.org/ research/women.htm (accessed February 6, 2016).

${ }^{5}$ John H. Johnson, ed., "Jill Brown May Be First Black Woman Navy Pilot," Jet, Vol. XLVII No.5, October 24, 1974, 19.

${ }^{6}$ Jeanne Holm, Women in the Military: An Unfinished Revolution ( Novato, CA: Presidio Press, 1982), 276.

${ }^{7}$ Ibid, 277.
} 
promoted again to Vice Admiral in 1976 and two years later was given the responsibility of commanding the U.S. Navy's 3 rd fleet. ${ }^{8}$ By 1975 , the U.S. Air Force had promoted its first black four-star General Daniel "Chappie" James. ${ }^{9}$ Ensign Thomasania Montgomery and Ensign Linda Rodriguez were the first African-American women to be commissioned as officers in the U.S. Coast Guard on June $5,1975 .{ }^{10}$ The first African American to be promoted to the rank of captain in the Coast Guard was Bobby C. Wilks in $1977 .{ }^{11}$ The Marine Corps also experienced change by appointing Frank E. Peterson (Figure 3.2) as the first African-American Marine Corps general in 1979.

\footnotetext{
${ }^{8}$ Lean'tin Bracks, African American Almanac: 400 years of Triumph, Courage and Excellence (Canton, MI: Visible Ink Press, 2012), 464.

${ }^{9}$ U.S. Department of Defense, http://www.defense.gov/home/features/2007/ BlackHistoryMonth/Timeline.html ${ }^{10}$ U.S. Coast Guard, "African Americans in Coast Guard History," http://www.uscg.mil/history/uscghist/African American Chronology.asp ${ }^{11} \mathrm{lbid}$.
} 
Figure 3.1

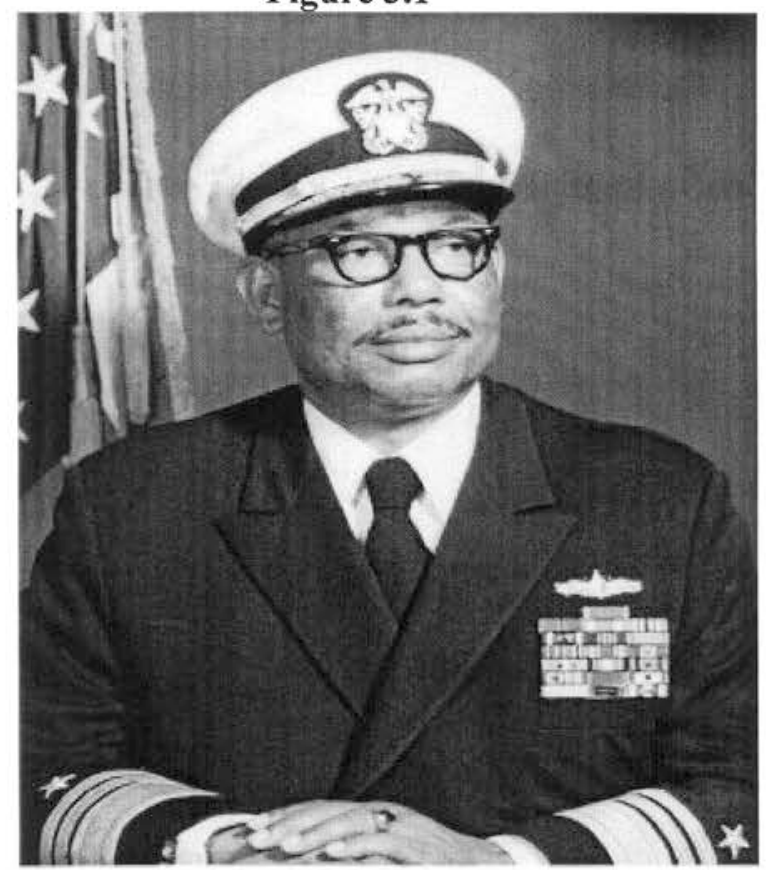

Above: Vice Admiral Samuel L. Gravely, Jr., U.S. Navy. Taken from U.S. Naval Institute, accessed April 13, 2016.

(https://www.navalhistory.org/2014/01/31)

Figure 3.2

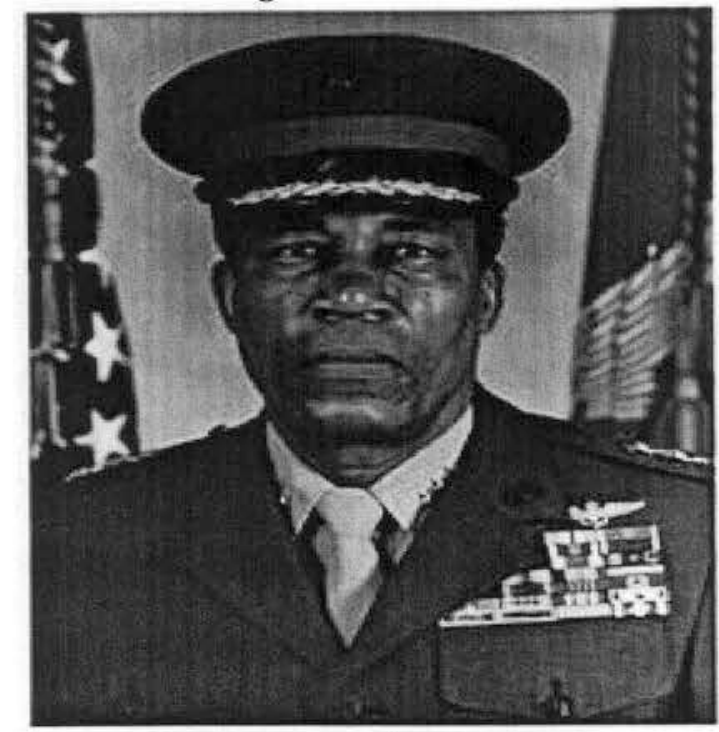

Above: Frank E. Petersen, Jr. First Black Marine Aviator and Brigadier General (deceased). Taken from U.S. Marine Corps, accessed February 20, 2016. 
It is one thing to recognize the progress of African Americans; it is another to think that their success was not supported by white Americans. In 1977 President Jimmy Carter appointed Clifford Alexander as Secretary of the Army, the first African American to head any branch of the U.S. military. His contributions to managing the new All Volunteer Force from 1977 to 1981 had a significant impact on black officers." ${ }^{\prime 2}$ His leadership led to a rise in the number of African-American General Officers, including Hazel Johnson who became the first black Brigadier General. ${ }^{13}$ One of the most successful black generals ever appointed by Secretary Alexander was Collin Powell. ${ }^{14}$ By 1984, the number of black generals/flag officers had risen to twenty-two in the Army, two in the Navy, eight in the Air Force and one in the Marine Corps ${ }^{15}$ Finally, in July 1998 the Coast Guard promoted Errol M. Brown to Rear Admiral making him the first African-American flag level officer. ${ }^{16}$

Additionally, there has been a turning point in the highest enlisted ranks that has continued for African Americans in the military. Although the USCG did not appoint any blacks to serve as Master Chief Petty Officer of the Coast Guard (MCPOCG) prior to 1975, in time things changed. The MCPOCG, the most senior enlisted rank and position in the Coast Guard appointed by the Commandant of the Coast Guard, addresses the issues of enlisted personnel to the

\footnotetext{
${ }^{12}$ U.S. Department of Defense, "African American History Month," 1970 to 1989, http://archive.defense.gov/home/features/2015/0215 aahm/ (accessed February 8, 2016).

${ }^{13}$ Ibid.

${ }^{14} \mathrm{Ibid}$.

${ }^{15}$ Defense Management Data Center, 3030 Report, September 30, 1984.

${ }^{16}$ U.S. Coast Guard, "Rear Admiral Erroll Brown, USCG," Office of Public Affairs, http://www.uscg.mil/history/people/Erroll Brown.asp (accessed February 8, 2016).
} 
Coast Guard high command. In 1998, Vincent W. Patton III (Figure 3.3) was

appointed as the eighth MCPOCG and served in that position from 1998 to

2002. ${ }^{17} \mathrm{He}$ became the first African American to hold the highest position for an

enlisted service member in the USCG. ${ }^{18}$

Figure 3.3

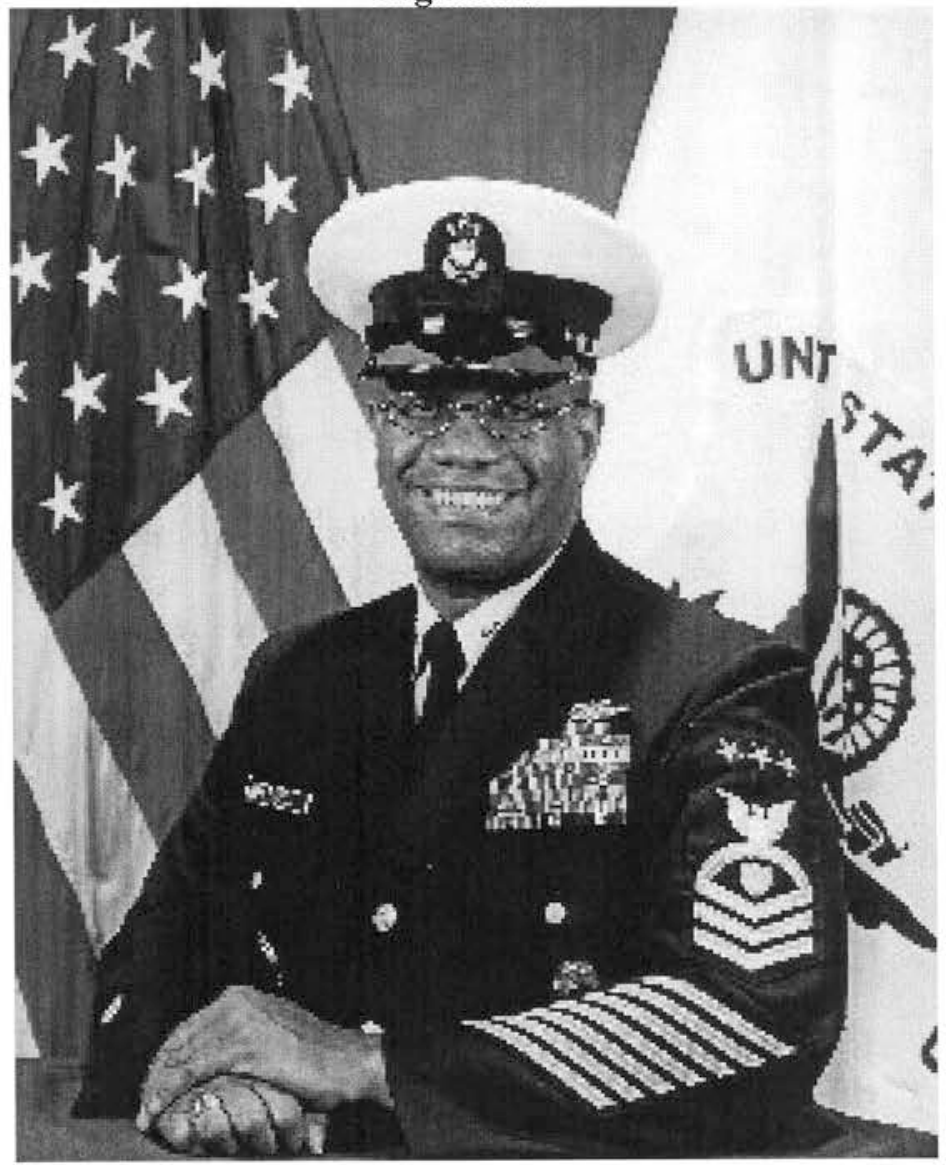

Above: Master Chief Petty Officer of the Coast Guard (MCPOCG) Vincent W. Patton, III, Taken from the U.S. Coast Guard, accessed February 9, 2016.

(http://www.uscg.mil/history/people/vincent_patton.asp)

${ }^{17}$ U.S. Coast Guard, "Vincent Patton," Historian's Office, January, 12, 2016. http://www.uscg.mil/history/people/vincent patton.asp

${ }^{18}$ U.S. Coast Guard, "African Americans in Coast Guard History," http://www.uscg.mil/history/uscghist/African American Chronology.asp 
In the late twentieth century, the Marine Corps trended in an unprecedented direction for their appointments to Sergeant Major of the Marine Corps (SgtMajMC). Since the first SgtMajMC appointment in 1957, the USMC had appointed no African American to such a position prior to 1975. The appointment of Alford L. Michael as SgtMajMC in 1999 made him the first African American to hold the title of Sergeant Major of the Marine Corps. ${ }^{19}$

Without question, the USMC acted in ways that have yet to be duplicated by any branch of service by 2015 . The USMC was the first and only branch of the military to have three or more African Americans to serve in the highest enlisted position. What made this even more unique was that it had three blacks that served right after each other. The first black to serve as SgtMajMC was Alford L. Michael from 1999 to $2003 .^{20}$ The second black to serve in the same position as the fifteenth SgtMajMC from 2003 to 2007, was John L. Estrada. ${ }^{21}$ The third was Carlton W. Kent, who served from 2007 to 2011 as the sixteenth SgtMajMC. ${ }^{22}$ Of all the branches of the military the Marine Corps was at one point the most resistant to black equality. However, African-American equality has continued to be on display for the world to see as the USMC appointed yet another African American to SgtMajMC in 2015. The appointment of Ronald L. Green (Figure

\footnotetext{
${ }^{19}$ U.S. Marine Corps, "Sergeant Major Alford L. MCMichael, USMC (Retired)," History Division, https://www.mcu.usmc.mil/historydivision/Pages/Who\%27s\%20Who/M-O/mcmichael al.aspx ${ }^{20}$ Ibid.

${ }^{21}$ U.S. Marine Corps, "Sergeant Major John L. Estrada, USMC (Retired)," History Division https://www.mcu.usmc.mil/historydivision/Pages/Who's\%20Who/D-F/Estrada JL.aspx ${ }^{22}$ U.S. Marine Corps, "Sergeant Major Carlton W. Kent, USMC (Retired)," History Division https://www.mcu.usmc.mil/historydivision/Pages/Who's\%20Who/J-L/Kent CW.aspx
} 
3.4) made him the eighteenth Sergeant Major of the Marine Corps, and the fourth African American to hold the job. ${ }^{23}$

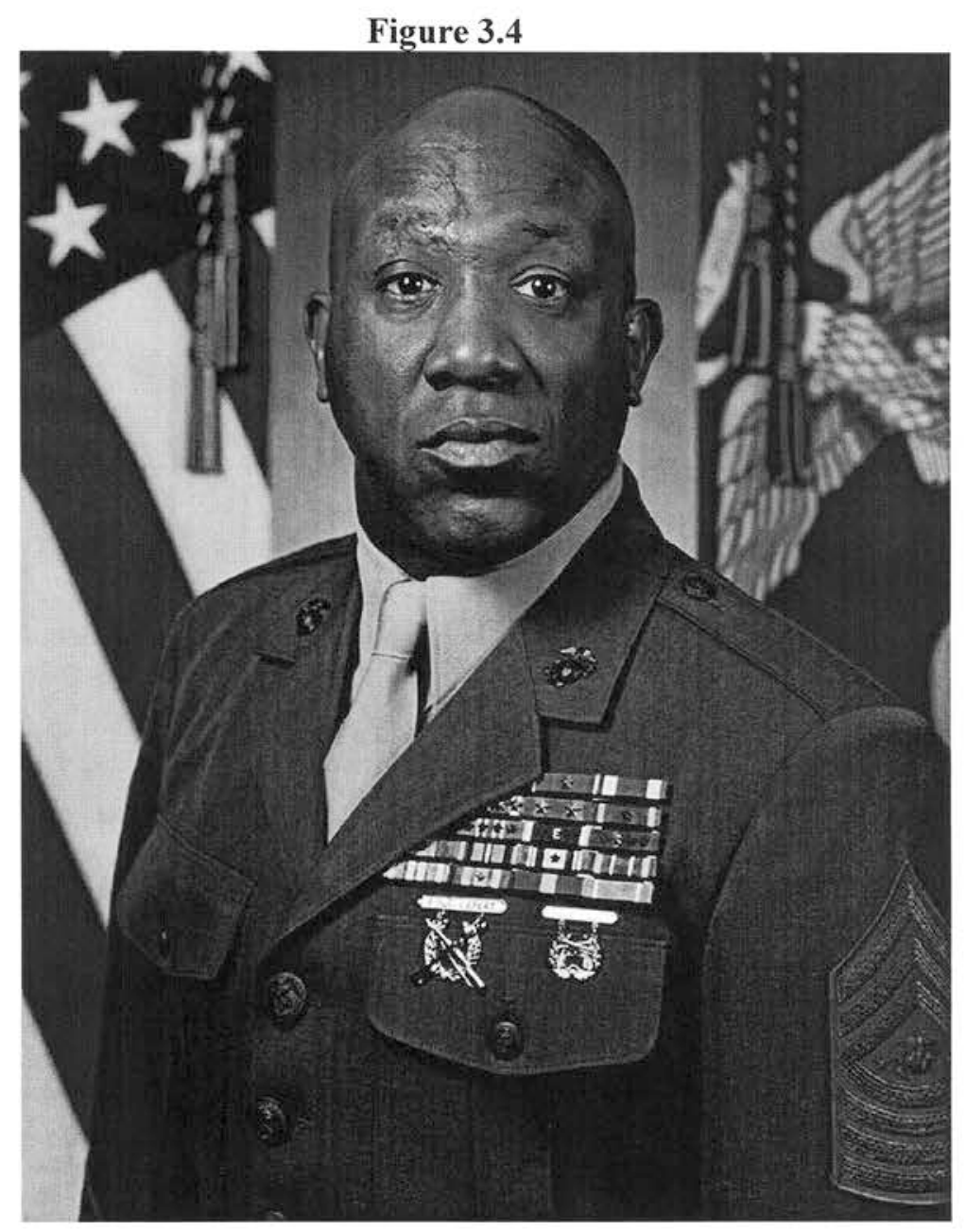

Above: Sergeant Major of the Marine Corps (SgtMajMC) Ronald L. Green, Taken from the United States Marine Corps, accessed February 10, 2016. (https://www.mcu.usmc.mil/historydivision)

\footnotetext{
${ }^{23}$ U.S. Marine Corps, "Sergeant Major Ronald L. Green, USMC," History Division https://www.mcu.usmc.mil/historydivision/Pages/Who's\%20Who/G-1/Green RL.aspx
} 
While examining the history of U.S. Army and the U.S. Air Force they had one thing in common in the positions of Sergeant Major of the Army (SMA) and Chief Master Sergeant of the Air Force (CMSAF). Prior to the1970s, neither branch had appointed an African American to either position. But things changed with the appointment of Thomas N. Barnes (Figure 3.5) as Chief Master Sergeant of the Air Force who held his position until $1977 .{ }^{24}$ Another noticeable step for black empowerment continued with the Army's appointment of Gene C.

McKinney as the first black SMA in 1995. Sergeant Major McKinney (Figure 3.6) served as the tenth SMA until his tenure ended in $1997 .{ }^{25}$ Although some might argue that one African-American promotion to such a position is not enough to justify equality, the evidence suggests that the progress of one will always be better than none.

\footnotetext{
${ }^{24}$ U.S. Air Force, "Chief Master Sergeant of the Air Force Thomas N. Barnes," Biographies, http://www.af.mil/AboutUs/Biographies.aspx

${ }^{25}$ U.S. Army, "Gene C. McKinney: 10th Sergeant Major of the Army," Biographies, http://www.army.mil/leaders/sma/former/sma bio10.html
} 
Figure 3.5

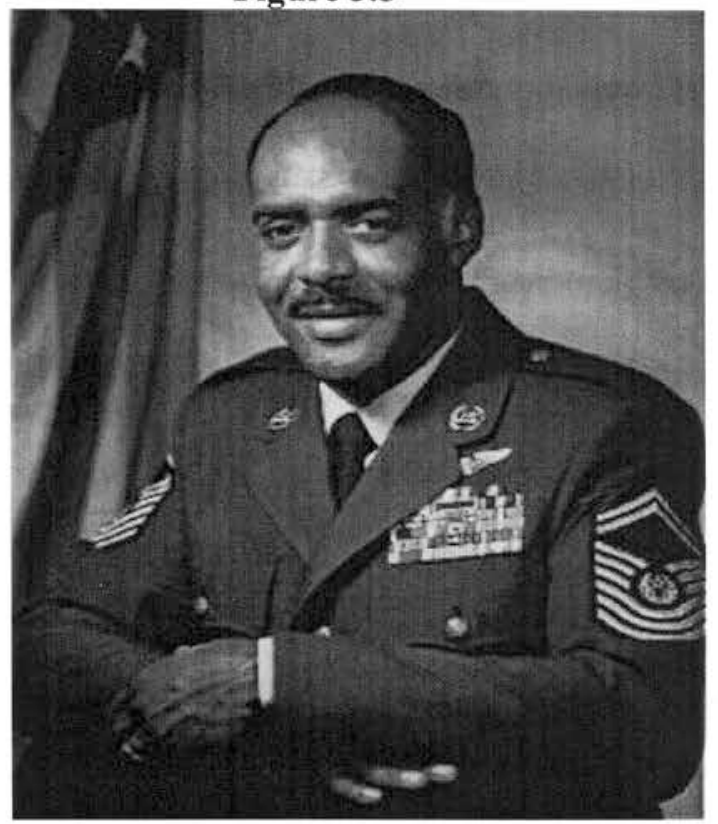

Above: Chief Master Sergeant of the Air Force (CMSAF) Thomas N. Barnes. Taken from the U.S. Air Force, accessed February 11, 2016. (http://www.af.mil/AboutUs/Biographies.aspx)

Figure 3.6

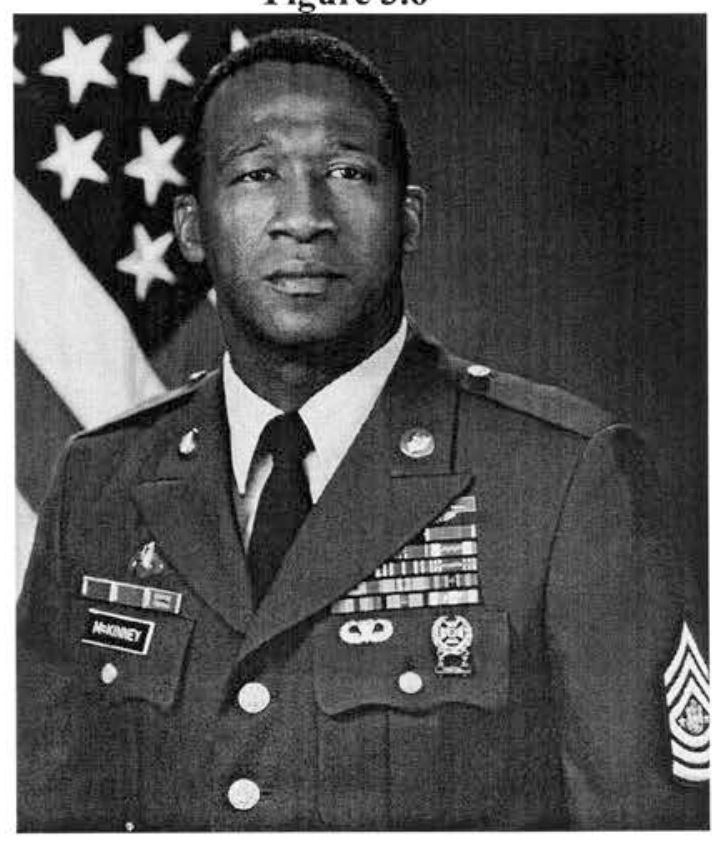

Above: Sergeant Major of the Army (SMA) Gene C. McKinney. Taken from the U.S. Army, accessed February 11, 2016. (http://www.army.mil/leaders/sma/former/sma_bio10.html) 
Whether reflecting on the 1970 s or 2000 s the Navy has continued to recognize the roles of black officers and enlisted sailors as some of the best and brightest trailblazers. ${ }^{26}$ Although the USN has yet to appoint any blacks to Master Chief Petty Officer of the Navy, it most certainly has appointed many blacks with the same rank of Master Chief Petty Officer to other key positions. For instance, Fleet Master Chief April D. Beldo (Figure 3.7) of the U.S. Navy has achieved much success in her career unlike any other African American.

\section{Figure 3.7}

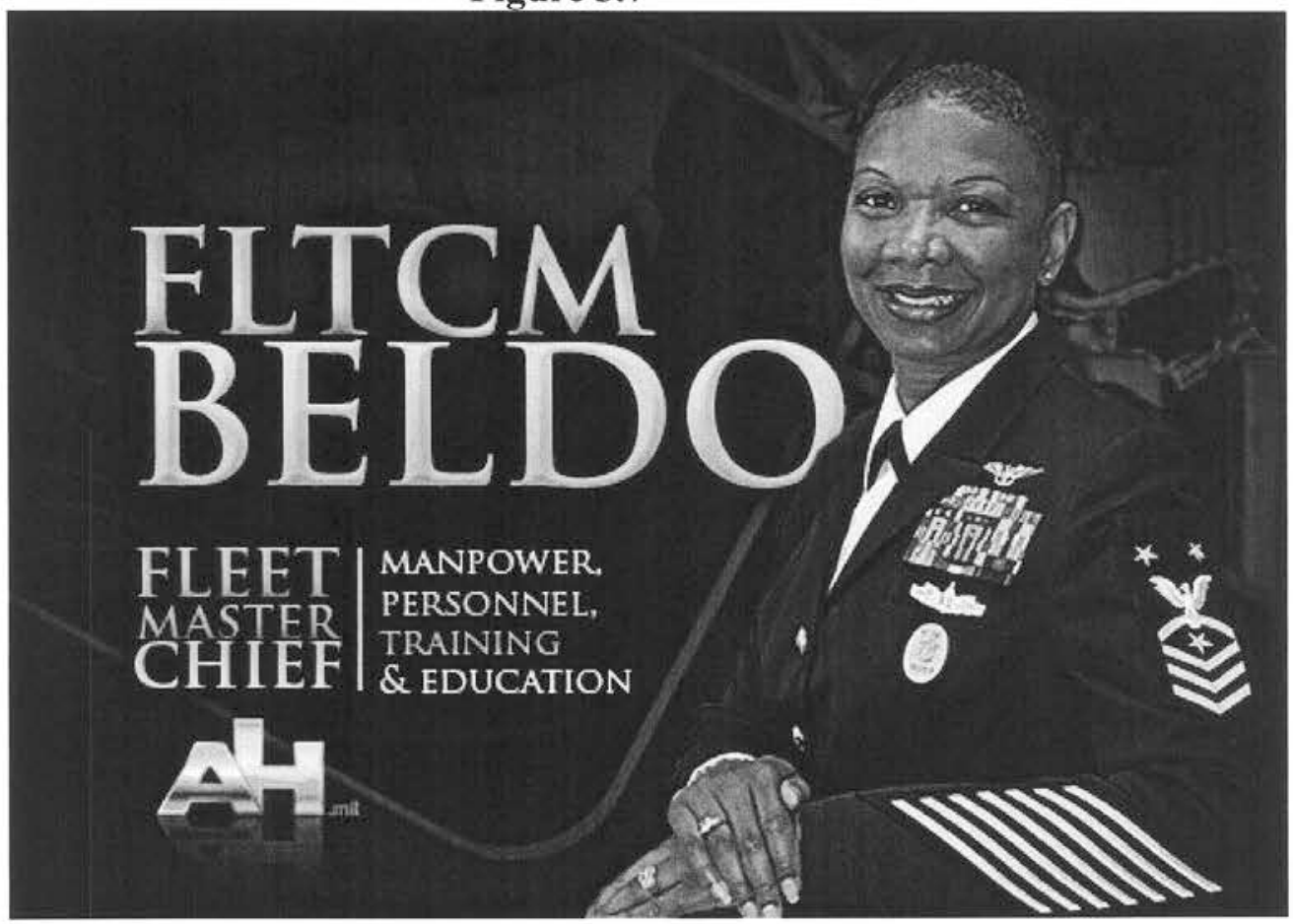

Above: Manpower, Personnel, Training and Education (MPT\&E) Fleet Master Chief (AW/SW) April D. Beldo. Taken from All Hands, accessed February 9, 2016. (http://www.navy.mil/ah_online/index.asp)

\footnotetext{
${ }^{26}$ Naval History and Heritage Command, "The African American Experience in the U.S. Navy," http://www.history.navy.mil/browse-by-topic/diversity/african-americans.html
} 
As an African American in the Navy, there is no denying that throughout her professional career FLTCM Beldo has continued to overcome the barriers that once hindered the rise of black women in the military. She accomplished many so-called "firsts" in the Navy as follows:

The first female command master chief $(\mathrm{CMC})$ of Recruit Training Command, Great Lakes, Ill.; first African-American female CMC of an aircraft carrier when assigned to USS Carl Vinson and the first female and African-American force master chief (FORCM) for Naval Education and Training Command. She is currently one of four fleet master chiefs (FLTCM) in the Navy and the first female FLTCM of MPT\&E, her current position. ${ }^{27}$

After reading such accomplishments, it is not surprising that an African American who always embraced responsibility at the highest levels would be promoted to some of the most prestigious billets in USN history. To argue that equality for black women in the Navy is not a reality due to discrimination or gender, would discredit Fleet Master Chief Beldo, who in her own words revealed "The qualification process is still the same, the criteria are the same, but the opportunity is there. Go for it!"28

As a consequence, it is impossible to argue that African Americans who are equipped with proper training and skills are still being denied their rightful place in the military hierarchy. To do so would dismiss all supporting evidence for black equality in the twenty-first century, including that which was displayed towards the end of 2015. On December 11, 2015, it was confirmed by the Senate that Major General Nadja West (Figure 3.8) would serve as the first African

\footnotetext{
${ }^{27}$ Brent Pyfrom, "Fleet Master Chief Beldo Talks Female Firsts and Chiefs' Prode," U.S. Navy, April 01, 2014. http://www.navy.mil/submit/display.asp?story id=80000 ${ }^{28} \mathrm{lbid}$.
} 
American and Forty-Fourth Army Surgeon General. ${ }^{29}$ Since graduating from the US Military Academy at West Point, she has became the highest ranking woman to hold the position of Lieutenant General. ${ }^{30}$ Despite the limited success of blacks in the military prior to 1975 , by 2015 , blacks were serving in some of the highest leadership positions in the U.S. military.

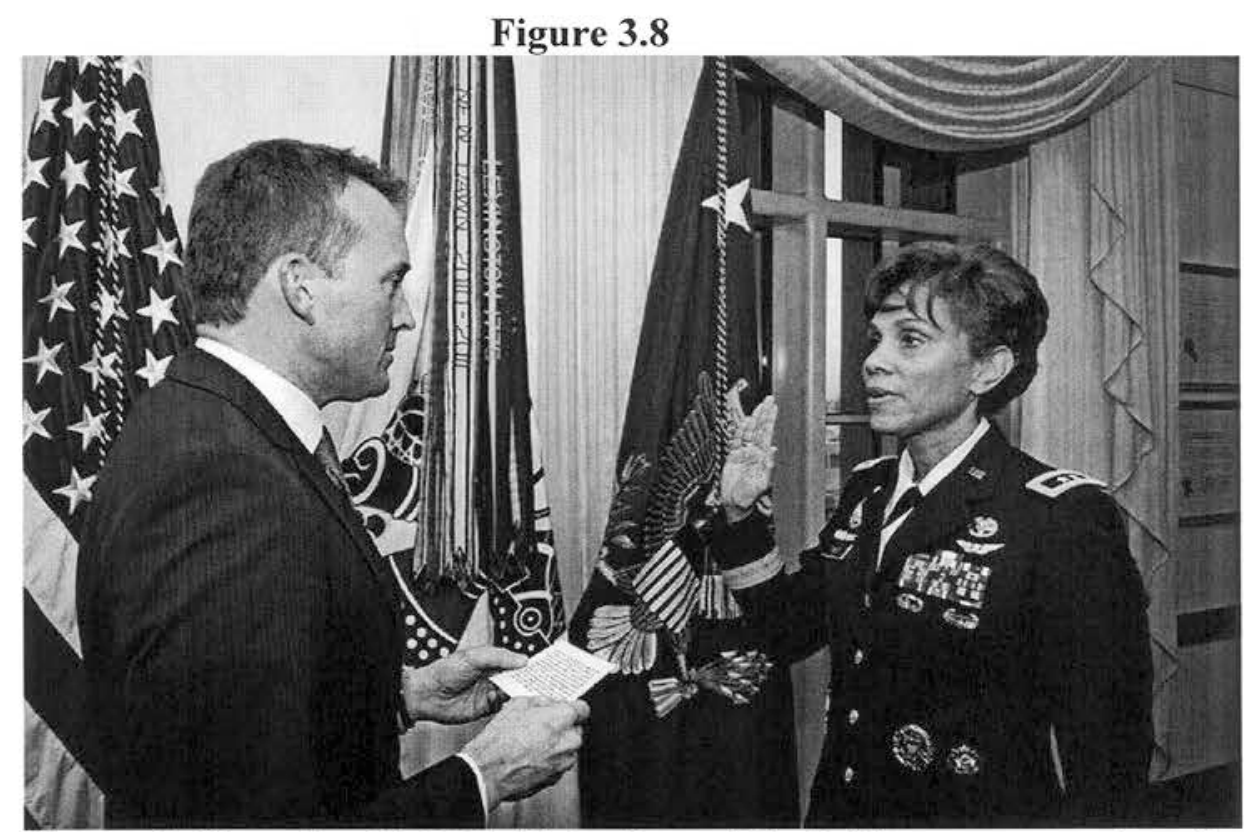

Above: On December 11, 2015, Major General Nadja West was sworn in as the 44th Army Surgeon General by Eric Fanning, Acting Secretary of the Army. Taken from the Unites States Army News Archives, accessed February 6, 2016. (http://www.army.mil/media/418701/)

Figure 3.9 shows three high ranking African-American women in the U.S.

Navy such as Adm. Michelle Howard, vice chief of Naval Operations, Rear Adm. Annie B. Andrews, commander, Navy Recruiting Command (NRC), and retired Rear Adm. Lillian E. Fishburne. Admiral Howard, Andrews, and Fishburne are the first three

\footnotetext{
${ }^{29}$ Maria Tolleson, "Maj. Gen. Nadja West confirmed as $44^{\text {th }}$ Army Surgeon General," The United States Army, December 11, 2015. http://www.army.mil/article/159884/Maj_Gen_Nadja _West_confirmed_as_44th_Army_Surgeon_General/ (accessed February 6, 2016). ${ }^{30} \mathrm{Ibid}$.
} 
African-American female admirals in the Navy. This illustration reveals black women

with very prestigious positions, with increased responsibility in the military.

Furthermore, Figure 3.9 reflects an absolute truth that barriers denying African

Americans the charge of responsibility in the military at the highest ranks exist no more regardless of race or gender.

\section{Figure 3.9}

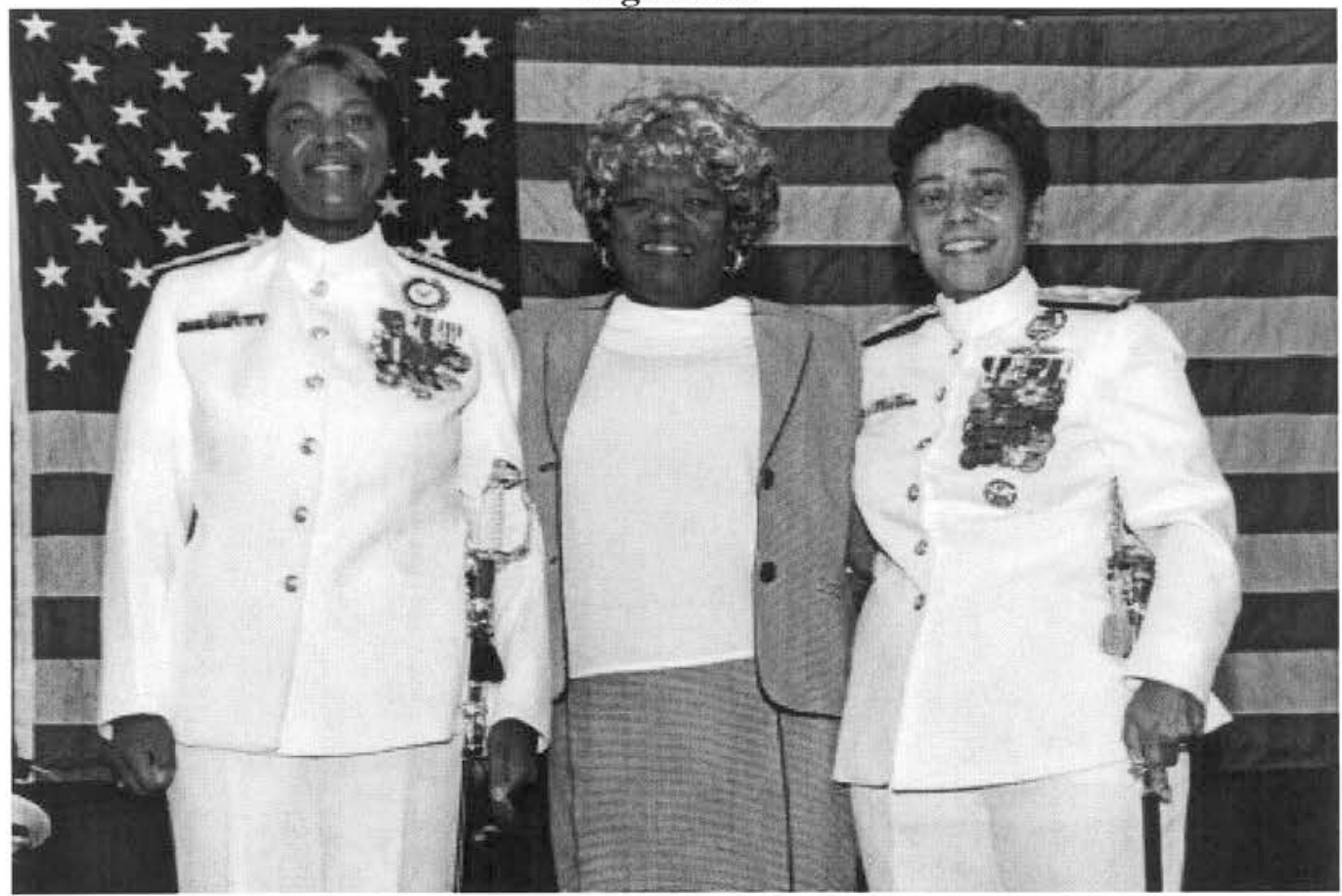

Above: Adm. Michelle Howard, vice chief of Naval Operations, Rear Adm. Annie B. Andrews, commander, Navy Recruiting Command (NRC), and retired Rear Adm. Lillian E. Fishburne stand on stage during NRC's change of command ceremony at Naval Support Activity Mid-South on September 4, 2015. NRC is responsible for recruiting the best men and women for America's Navy, Taken from U.S. Navy, photo by Mass Communication Specialist 2nd Class Scott Bigley/Released.

In an effort to recognize the heroic contributions of African Americans, the U.S. military even began naming ships after blacks in the U.S. Navy. In total, the U.S Navy has named ten ships after African Americans. One of the first 
destroyers to be named after an African-American service member in the USN was the USS Oscar Austin (DDG-79) ${ }^{31}$ It was the first ship built in the Flight IIA Arleigh Burke class of guided missile destroyers. ${ }^{32}$ This ship was named after an African-American Marine who posthumously received the Medal of Honor, for his heroic actions to save a wounded marine who fell unconscious during a battle in the Vietnam War in which he "resolutely threw himself between the marine and the enemy, and in so doing, fell mortally wounded."${ }^{\prime 33}$ The ship was commissioned on August 19, 2000 and as of 2015 is still active in the U.S. Naval Fleet.

Another ship that was commissioned in honor of an African American was the USS Gravely (DDG 107). This ship was built to pay tribute to Vice Admiral Samuel Lee Gravely, Jr., who was the Navy's first black Admiral. Through his actions and words, Vice Admiral Gravely emphasized his notion of equality in his belief that:

Success in life is the result of several factors. My formula is simply education plus motivation plus perseverance. Education is paramount. Motivation: one must decide what he wants to do in life, how best to get there and to proceed relentlessly towards that goal. Perseverance: the ability to steadfastly proceed to your goal despite all obstacles. ${ }^{34}$

\footnotetext{
${ }^{31}$ Naval History and Heritage Command, "The African American Experience in the U.S. Navy," http://www.history.navy.mil/browse-by-topic/diversity/african-americans.html ${ }^{32}$ Ibid.

${ }^{33} \mathrm{lbid}$.

${ }^{34}$ Regina T. Akers, "Vice Adm. Samuel L. Gravely, Jr., USN: Naval Officer, Trailblazer," U.S. Naval Institute, January 31, 2014. http://www.navalhistory.org/2014/01/31/vice-adm-samuel-Igravely-ir-usn-naval-officer-trailblazer-prepared-by-regina-t-akers-ph-d-historian-naval-historyand-heritage-command
} 
The significance of his belief is that the obstacles he overcame were trailblazing

for all blacks in the Navy. Gravely was a distinguished sailor who led by example throughout his entire naval career until he retired in August 1980. His many accomplishments include:

The first African American to command a U.S. Navy warship (USS Theodore E. Chandler); the first African American to command an American warship under combat conditions since the Civil War (USS Taussig); the first African American to command a major naval warship (USS Jouett); the first African American admiral; the first African American to rise to the rank of vice admiral; and the first African American to command a U.S. Fleet (Commander, 3rd Fleet). ${ }^{35}$

On November 20, 2010, the commissioning of USS Gravely (DDG-107) became a historical highlight in honor of the 38 years that Vice Admiral Gravely devoted to his country. ${ }^{36}$

Another branch of service to name a ship after an African American was the U.S. Coast Guard. Although Coast Guard cutters are not normally named after people, it was Robert Browning, chief historian for the U.S. Coast Guard who said "I think he's a great role model for kids." ${ }^{\text {"37 }}$ The USCG named the USCGC Healy (WABG 20), a member of the icebreaking fleet "for Michael Healy, in acknowledgment of his inspiring commitment to the Service, including his invaluable assistance to Alaska Natives." ${ }^{138}$ Born the son of an Irish plantation

${ }^{35}$ Department of the Navy, "Vice Admiral Samuel Lee Gravely, Jr.," United States Navy Biography, http://www.navy.mil/navydata/bios/bio.asp?biolD $=844$

${ }^{36}$ Naval History and Heritage Command, "The African American Experience in the U.S. Navy," http://www.history.navy.mil/research/histories/ship-histories/danfs/g/Gravely.html

${ }^{37}$ Academic Search Premier, "Michael Augustine Healy," BLACFAX, January 15, 2003, Vol. 11, No. 42, 11-14. (accessed February, 15, 2016).

${ }^{38}$ U.S. Coast Guard, "African Americans in the United States Coast Guard," Historians Office, January 12, 2016. http://www.uscg.mil/history/articles/h africanamericans.asp 
owner and slave mother from Georgia, Captain Healy had to hide his true racial identity of being black so he could pursue a military career in the nineteenth century from 1864 to $1895 .{ }^{39}$ Although he was believed to be Irish, Healy was indeed one of the first blacks to promote to Captain in 1883 while commanding several Coast Guard Cutters from 1883 to $1895 \cdot{ }^{40}$ Despite how long it took to recognize Captain Healy for his service, the USCG commissioned USCGC Healy on August 21, 2000 and it is still currently active. ${ }^{41}$

Additionally, the tributes and honoring of African Americans was not just done by the USN and the USCG. The U.S. Marine Corps also contributed to honoring African Americans for their service ensuring that their legacies would live on. In 1974 the USMC had renamed Montford Point, which was the first training camp for African American Marines from 1942 to 1949 to Camp Gilbert H. Johnson. ${ }^{42}$ Initially this was a segregated training camp for African Americans until the military was fully integrated by 1949 . Despite such a dark beginning, Camp Johnson is now a Marine Corps base comprised of four military specialty schools, several tenant commands, and one Marine Corps O6 level Command. ${ }^{43}$ The renaming of Montford Point is indeed a tribute to Sergeant Major Gilbert H. Johnson.

When looking at the history of Camp Johnson, it was remarkable to discover that over 20,000 African-American Marines performed honorable

${ }^{39}$ U.S. Coast Guard, "CGC Healy History," http://www.uscg.mil/pacarea/cgchealy/history.asp

${ }^{40}$ Ibid.

${ }^{41} \mathrm{lbid}$.

${ }^{42}$ U.S. Marine Corps, "Marine Corps Combat Service Support Schools," Camp History, http://www.mccsss.marines.mil/CampJohnson/CampHistory.aspx

${ }^{43} \mathrm{lbid}$. 
service during the World War II era. ${ }^{44}$ Long overdue for public recognition, in 2012:

Congress authorized the Congressional Gold Medal to be awarded to each of the 20,000 Montford Point Marines or to their families in recognition of the accomplishments and sacrifices made during a time of segregation. ${ }^{45}$

The awards given to the Montford Point Marines by Congress was the highest civilian honor awarded as an expression of national gratitude for the social change that they inspired in the Marine Corps that still exist today.

To some historians, the history of African American contributions in the Army, particularly the Civil War, was often forgotten prior to 1975. After 1975 several monuments to honor the sacrifices of Colored Regiments were being erected all over the country. Figure 3.10 is the first monument to capture the entire African-American experience during the Civil War and began construction in 1997 with Congressional approval. ${ }^{46}$ The purpose of this memorial, which opened in 1999, was to commemorate the sacrifices made by the AfricanAmerican soldiers who served the Union Army during the Civil War. Figure 3.10 has over 209,000 names on the Wall of Honor for the Civil War Memorial to serve as a constant reminder of the African-American soldiers who fought for freedom in the United States Colored Troops (USCT). ${ }^{47}$ Though this memorial (Figure 3.10) was erected over 133 years after the Civil War, it symbolizes

\footnotetext{
${ }^{44}$ Corporal Elizabeth Thurston, "91 Year Old Montford Point Marine Veteran Receives Congressional Gold Medal," U.S Marine Corps, February 9, 2015.

45 Ibid.

46 "African American Civil War Memorial," Civil War Times Illustrated, October 1996, Vol 35, No.

5, 12. (accessed February 20, 2016).

47 "USCT History," African American Civil War Memorial and Museum, Washington, DC. https://afroamcivilwar.org/about-us/memorial-museum-history.html
} 
African-American sacrifice for the Union. President Lincoln who acknowledged the honorable contributions of blacks said "Without the military help of the black freedmen, the war against the South could not have been won." ${ }^{\text {48 }}$

By recognizing the faithful and honourable service of the brave African Americans who have served in the armed forces, the military has taken steps in a variety of ways to right the "wrongs" of Americas past. In the end, the United States military and Congress have worked continuously to ensure that the quality of life for African Americans in the military is one of equality and respect. Of course, the only real way to continue assessing the trends for African-American equality in all branches of the U.S. military is with time.

${ }^{48}$ Ibid. 
Figure 3.10

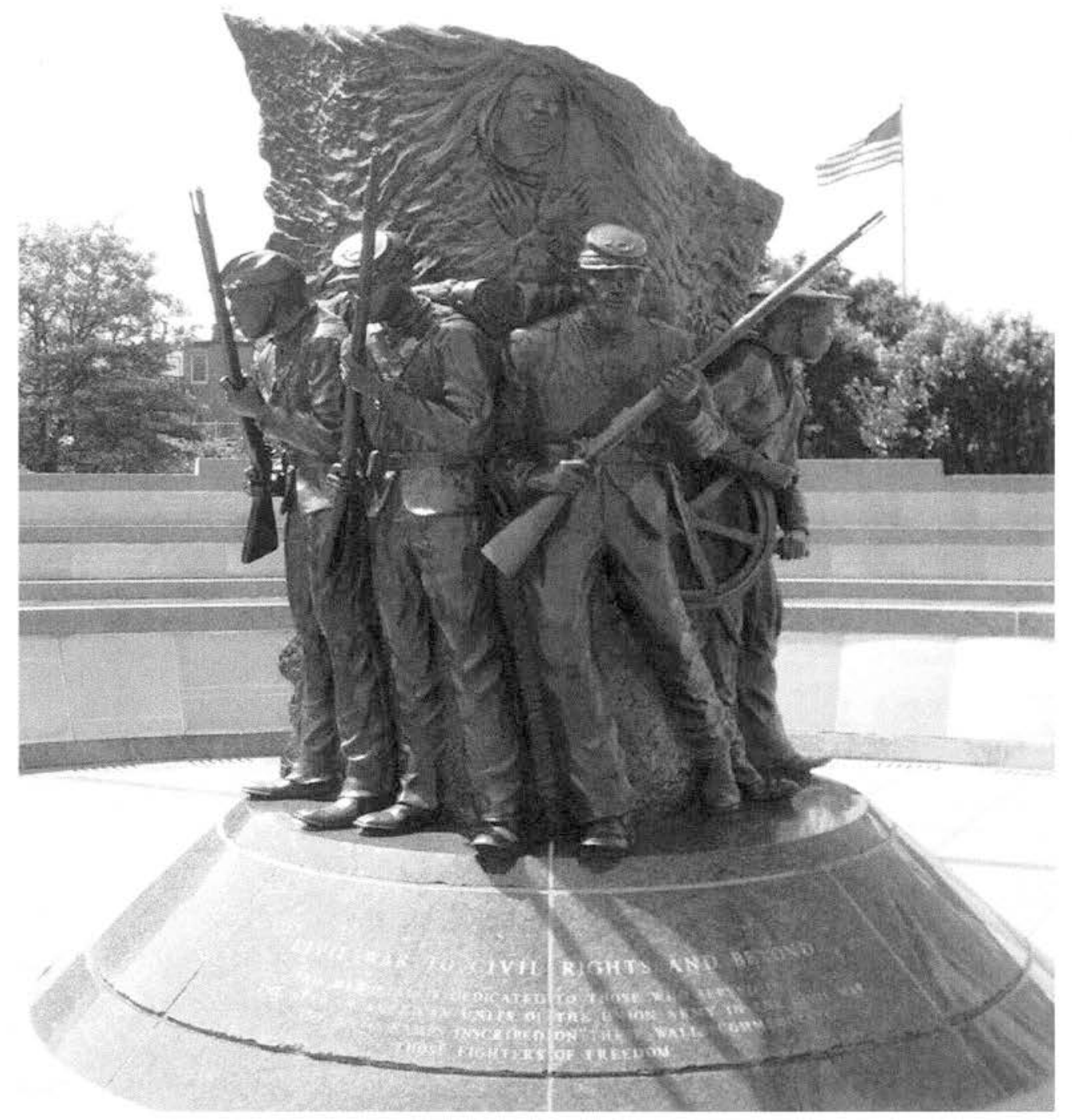

Above: The African American Civil War Memorial erected in 1999 in Washington, DC to pay tribute to the black soldiers that fought for freedom during the Civil War as part of the Union Army as members of the USCT. Taken from the African American Civil War Memorial and Museum, accessed February 20, 2016. 


\title{
Chapter Four
}

\author{
Conclusion
}

Between 1975 and 2015 support for African American equality in the U.S military has increased tremendously. Using data that was available after the establishment of the AVF, it was possible to illustrate how the quality of life for African Americans in the military has changed over the years. This thesis was able to capture the trends in African American military service from 1975 to 2015. The continued increase in black military representation is noted in Table 4.1, which reflect both the officer and enlisted ranks after 1975. In fact, Table 4.1 shows that while black enlisted personnel were just below an average of 14 percent in the military by 1975 , they were right above 21 percent by $2001 .^{1}$ Furthermore, it reflects a rise in black officers above eight percent by 2001 compared to just three percent in 1975 .

When we look at blacks in the military prior to 1975 on Table 4.2, we see an interesting change. Table 4.2 shows that by 1975 the percentage of blacks in the military was trending upward. In the Army and the Air Force, there was an increase in the percentage of black officers and enlisted ranks from 1949 to 1975. Among the Navy and the Marine corps the same trend was true. Table 4.2 shows that by 1975 , black officers in the Navy and Marine Corps had more than doubled in comparison to the 1960 s and early 1970 s. What is certain when examining

\footnotetext{
${ }^{1}$ Department of Defense, Population Representation in the Military Services, FY2002 (2004), tables D-17, D-27.
} 
Table 4.2 is that the percentage of blacks in the enlisted ranks increased by an average of fifty percent in all branches of the armed forces from 1970 to $1975 .^{2}$

Considering the number of black women serving in the military after 1975 , the trend toward equality is more pronounced. Table 4.3 examined black women in the military in the 1960s and 1970s. Although this table shows a decline in black women officers in all services from 1970 to 1975, the percentage of black women in comparison to total women increased during the same years. ${ }^{3}$ In fact, the percentage of black women officers more than doubled in every branch, except for the Army and the Air Force, by $1975 .{ }^{4}$

Looking at the military from 1995 to 2013 , research provides another statistical perspective of black opportunity in the military. Though some might still choose to argue against equal opportunity for blacks, it is impossible to overlook the tremendous number of black military officers by 2013 . The evidence suggests that African Americans comprise twenty percent of all officers in the armed forces. ${ }^{5}$ Furthermore, from 1995 to 2013, the number of black officers has doubled. ${ }^{6}$ On the other hand, from 1995 to 2013, blacks in the enlisted ranks saw a significant decrease in the Army and Marine Corps: The Navy and the Air Force, meanwhile increased slightly. ${ }^{7}$

\footnotetext{
${ }^{2}$ U.S. Department of Defense, and U.S. Commission on Civil Rights, 1963 Report, Washington, 1963.

${ }^{3}$ Ibid.

${ }^{4}$ Ibid.

${ }^{5}$ Department of Defense, "2013 Demographics Report," Demographic Reports, 25. http://www.militaryonesource. $\mathrm{mil} /$ footer?content id=279104 (accessed February 16, 2016). ${ }^{6}$ Ibid.

${ }^{7}$ Ibid.
} 
By 2014 the U.S. military was comprised of 1,326,273 active duty military personnel. ${ }^{8}$ Almost one third of the active duty members were minorities, including blacks. In fact, the proportion of military personnel that identified themselves as a minority was more in 2014 than it was in 1995. Such a percentage, which reflected $28.2 \%$ of enlisted members and $10.5 \%$ of officers in 1995 , increased to to $32.9 \%$ of enlisted members and $22.5 \%$ of officers by $2014 .{ }^{9}$ Furthermore, the overall ratio of 359, 056 minority enlisted personnel to the 53, 014 minority officers shows there is roughly 6.8 minority enlisted personnel for every one minority officer. ${ }^{10}$ The numbers illustrate that by 2014 , blacks viewed the military as a career opportunity providing upward mobility and equality.

Finally it has become clear that this thesis has determined that equality for African Americans serving in the military has improved dramatically after 1975. The rise in rank of African Americans in the military has been nothing short of remarkable. By 2015, African Americans in the military haven been given the charge of responsibility in some of the most prestigious positions in all branches of the military than ever before. With an increase in opportunities such as education, housing, pay, promotions, achievements, and tributes it is time to acknowledge that blacks are no longer subjected to second-class citizenship. What is absolute above all else is that by 2015 African Americans were capable of achieving any position in any branch of the military for which they are qualified.

\footnotetext{
${ }^{8}$ Department of Defense, "2014 Demographics Report," Demographic Reports, November 02, 2015, 18. http://www.militaryonesource.mil/footer?content id=279104 (accessed February 18, 2016).

${ }^{9}$ Ibid.

${ }^{10}$ Ibid.
} 
Moreover, this analysis shows how the U.S. military is color blind and treats all its members with the dignity and respect that they deserve. 
Table 4.1

African American Share of Enlisted Personnel and Officers, by Service, 1973-2002

Percent of enlisted personnel

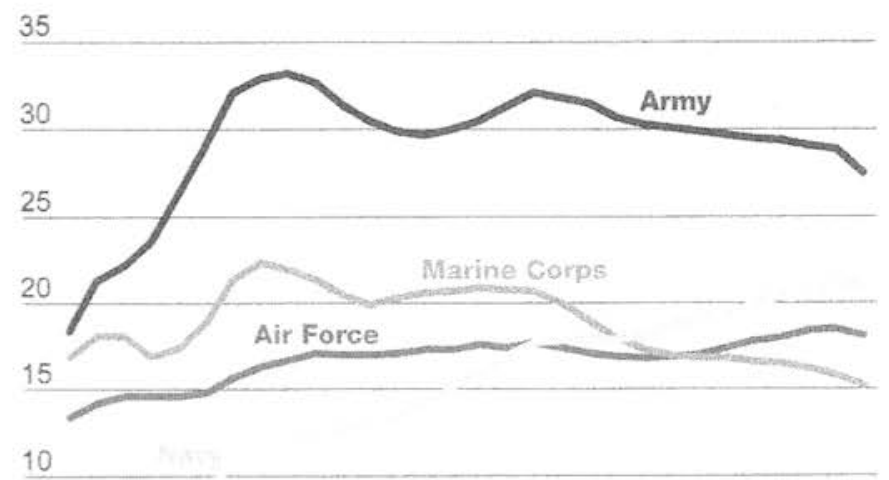

5

\begin{tabular}{|c|c|c|c|c|c|c|c|}
\hline $0_{1}$ & 1 & 1 & 1 & 1 & 1 & $\perp$ & 1 \\
\hline 1973 & 1977 & 1981 & 1985 & 1989 & 1993 & 1997 & 2001 \\
\hline
\end{tabular}

Percent of officers

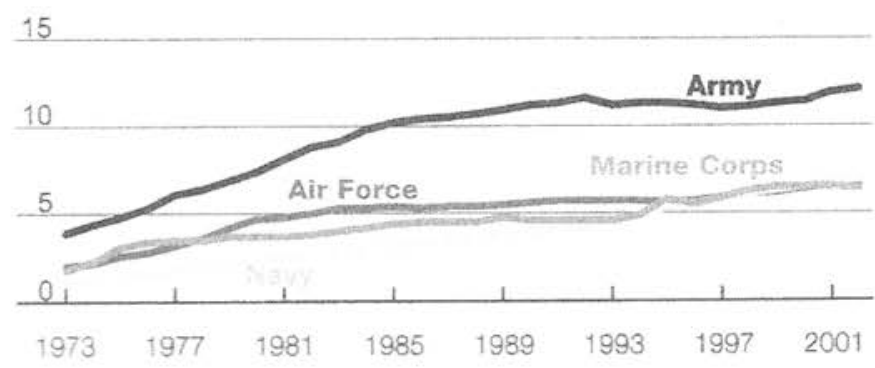

Source: DoD, Population Representation in the Military Services, FY2002 (2004): wables D-17, D-27 
Table 4.2

Black Ammad Forces Persennal as a Percent of All Amod Forces Peresnnel by Oificer-Enilisted Status and Type of Service for Selected Years: 1945 to 1975

\begin{tabular}{|c|c|c|c|c|c|c|}
\hline M111tary service and status & 1945 & 1949 & 1964 & 1967 & 1970 & 1975 \\
\hline Al1 services $\ldots \ldots \ldots \ldots \ldots \ldots \ldots \ldots$ & (NA) & 6.7 & 8.7 & 9.0 & 9.8 & 16.3 \\
\hline 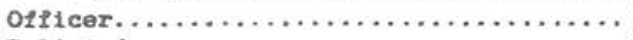 & (HA) & 0.9 & 1.8 & 2.1 & 2.2 & 3.1 \\
\hline 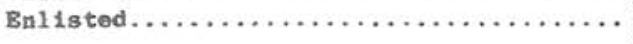 & (NA) & 7.4 & 9.7 & 9.9 & 11.0 & 16.1 \\
\hline 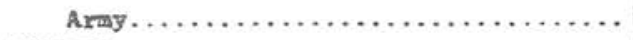 & (MA) & 10.1 & 10.9 & 11.2 & 12. 2. & 19.9 \\
\hline 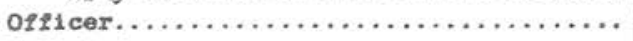 & ${ }^{2} 0.7$ & 1.9 & 3.3 & 3.4 & 3.4 & 4.8 \\
\hline Bnlisted. $\ldots \ldots \ldots \ldots \ldots \ldots \ldots \ldots \ldots \ldots$ & ${ }^{1} 10.3$ & 11.1 & 11.8 & 12.1 & 13.5 & 22.2 \\
\hline 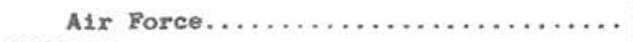 & (NA) & 5.3 & 8.6 & 9.1 & 10.0 & 12.5 \\
\hline 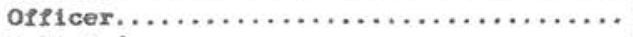 & (NA) & 0.6 & 1.5 & 1.8 & 1.7 & 2.5 \\
\hline 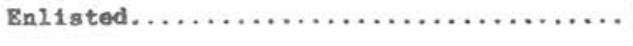 & (NA) & 6.1 & 10.0 & 10.4 & 11.7 & 14.6 \\
\hline 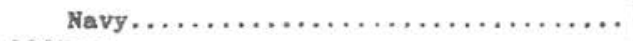 & (NA) & 4.0 & 5.3 & 4.3 & 4.8 & 7.2 \\
\hline 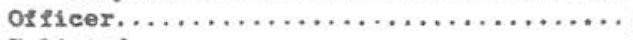 & - & - & 0.3 & 0.3 & 0.7 & 1.4 \\
\hline 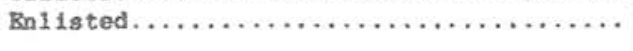 & 4.8 & 4.4 & 5.9 & 4.7 & 5.4 & 8.0 \\
\hline 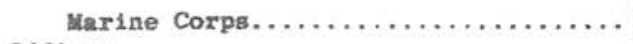 & (NA) & 2.3 & 7.9 & 10.3 & 10.2 & 16.7 \\
\hline 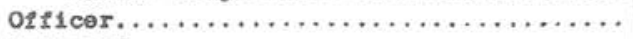 & (NA) & 0.1 & 0.3 & 0.7 & 1.3 & 3.0 \\
\hline 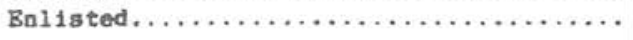 & (RA) & 2.5 & 8.7 & 9.6 & 11.2 & 18.1 \\
\hline
\end{tabular}

- Ropresents zero.

NA Not available.

${ }^{2}$ Includes A1s Force personnel.

Source: U.S. Department of Delense, and U.S. Counlssion on Civi2 Rights, 1963 Report, Vashington, 1963.

Table 4.3

Participation of Black Women in the Armed Forces by Type of Service: 1966, 1970, and 1975

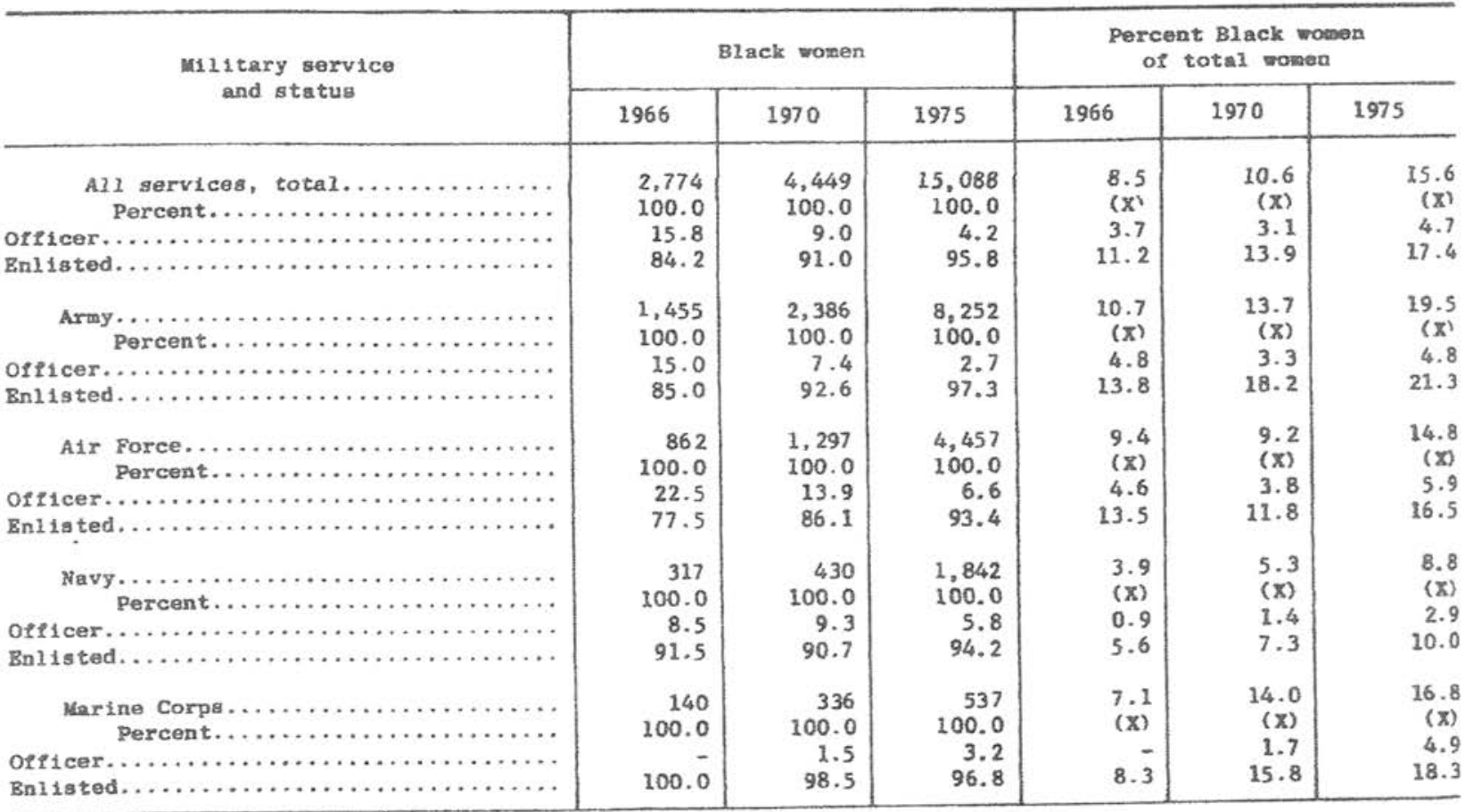

- Represents or rounds to zero.

$X$ Not applicable.

Source: U.S. Department of Defense. 


\section{Appendix I}

\section{African American Medal of Honor Recipients ${ }^{1}$}

List of recipients have been verified through many sources including

Congressional research documents. African Americans who received their awards posthumously are identified with a $(\mathrm{P})$ and those who were alive are identified with an (A).

NAME

ANDERSON, Bruce

ANDERSON, James

ANDERSON, Webster

ASHLEY, Eugene

ATKINS, Daniel

AUSTIN, Oscar

BAKER, Edward

BAKER, Vernon

BARNES, William

BEATY, Powhatan

BELL, Dennis

BLAKE, Robert

BOYNE, Thomas

BRONSON, James

BROWN, William

BROWN, Wilson

BROWN, Benjamin

BRYANT, William

CARNEY, William

\section{CONFLICT}

Civil War

Vietnam

Vietnam

Vietnam

Non-Combat 1871-1899

Vietnam

War with Spain

WWII

Civil War

Civil War

War with Spain

Civil War

Indian Campaigns

Civil War

Civil War

Civil War

Indian Campaigns

Vietnam

Civil War

\section{BRANCH}

U.S. Army

U.S. Marine Corps

U.S. Army

U.S. Army

U.S. Navy

U.S. Marine Corps

U.S. Army

U.S. Army

U.S. Colored Troops

U.S. Colored Troops September 29,1864 (A)

U.S. Army

U.S. Navy

U.S. Army

U.S. Colored Troops September 29,1864 (A)

U.S. Navy

U.S. Navy

U.S. Army

U.S. Army

U.S. Colored Troops July 18, 1863 (A)
June 30, 1898 (A)

December 25,1863 (A)

September 27,1879 (A)

August 5, 1864 (A)

August 5, 1864 (A)

May $11,1889(\mathrm{~A})$

March 24, 1969 (P)

\footnotetext{
${ }^{1}$ Medal of Honor Historical Society of the United States, email message to author, January 11, 2015
} 


\begin{tabular}{|c|c|c|c|}
\hline CARTER, Edward & WWII & U.S. Army & January $13,1997(\mathrm{P})$ \\
\hline CHARLTON, Cornelius & Korean War & U.S. Army & March 19, $1952(\mathrm{P})$ \\
\hline DAVIS, Rodney & Vietnam & U.S. Marine Corps & September 6, 1967 (P) \\
\hline DAVIS, John & War with Spain & U.S. Navy & May $11,1898(\mathrm{~A})$ \\
\hline DAVIS, John & Non-Combat 1871-1898 & U.S. Navy & February $1881(\mathrm{~A})$ \\
\hline DENNY, John & Indian Campaigns & U.S. Army & September 18,1879 \\
\hline DORSEY, DeCatur & Civil War & U.S. Colored Troops I & November 8,1865 (A) \\
\hline FACTOR, Pompey & Indian Campaigns & U.S. Army & April 25, 1875 (A) \\
\hline FLEETWOOD, Christian & Civil War & U.S. Colored Troops & September $29,1864(\mathrm{~A})$ \\
\hline FOX, John & WWII & U.S. Army & January $13,1997(\mathrm{P})$ \\
\hline GARDINER, James & Civil War & U.S. Colored Troops & September 29,1864(P) \\
\hline GIRANDY, Alphonse & Non-Combat 1901-1910 & U.S. Navy & March 31, 1901 (A) \\
\hline GREAVES, Clinton & Indian Campaigns & U.S. Army & June 26,1879 (A) \\
\hline HARRIS, James & Civil War & U.S. Colored Troops & September 29,1864 (P) \\
\hline HAWKINS, Thomas & Civil War & U.S. Colored Troops J & July 21,1864 (A) \\
\hline HILTON, Alfred & Civil War & U.S. Colored Troops & September 29,1864 (P) \\
\hline HOLLAND, Milton & Civil War & U.S. Colored Troops & September 29,1864 (A) \\
\hline JAMES, Miles & Civil War & U.S. Colored Troops & April 6, 1865 (A) \\
\hline JAMES, Willy & WWII & U.S. Army & January 13, $1997(\mathrm{P})$ \\
\hline JENKINS, Robert & Vietnam & U.S. Marine Corps & March 5, $1968(\mathrm{P})$ \\
\hline JOEL, Lawrence & Vietnam & U.S. Army & November 8,1965 (A) \\
\hline JOHNSON, Henry & WWI & U.S. Army & June 2, 2015 (P) \\
\hline JOHNSON, John & Non-Combat 1871-1899 & U.S. Navy & April 12, 1872 (A) \\
\hline JOHNSON, William & Non-Combat 1871-1899 & U.S. Navy & November 14,1879 (A) \\
\hline JOHNSON, Dwight & Vietnam & U.S. Army & November 19, 1968 (A) \\
\hline JOHNSON, Ralph & Vietnam & U.S. Marine Corps & March 5, $1968(\mathrm{P})$ \\
\hline JORDAN, George & Indian Campaigns & U.S. Army & May $14,1880(A)$ \\
\hline KELLY, Alexander & Civil War & U.S. Colored Troops & s September $29,1864(\mathrm{~A})$ \\
\hline
\end{tabular}




\begin{tabular}{|c|c|c|c|}
\hline LANGHORN, Garfield & Vietnam & U.S. Army & January $15,1969(\mathrm{P})$ \\
\hline LAWSON, John & Civil War & U.S. Navy & August 5, 1864 (A) \\
\hline LEE, Fitz & War with Spain & U.S. Army & June 30,1898 (A) \\
\hline LEONARD, Matthew & Vietnam & U.S. Army & February 28, $1967(\mathrm{P})$ \\
\hline LONG, Donald & Vietnam & U.S. Army & April 4, $1968(\mathrm{P})$ \\
\hline MAYS, Isaiah & Indian Campaigns & U.S. Army & May $11,1889(\mathrm{~A})$ \\
\hline McBryar, William & Indian Campaigns & U.S. Army & March 7, $1890(\mathrm{~A})$ \\
\hline MIFFLIN, James & Civil War & U.S. Navy & August $5,1864(\mathrm{~A})$ \\
\hline Morris, Melvin & Vietnam & U.S. Army & March 18, 2015(A) \\
\hline NOIL, Joseph & Non-Combat 1871-1899 & U.S. Navy & December 26,1872 (A) \\
\hline OLIVE, Milton & Vietnam & U.S. Army & April 26, $1966(\mathrm{P})$ \\
\hline PAINE, Adam & Indian Campaigns & U.S. Army & September 27,1874 (A) \\
\hline PAYNE, Isaac & Indian Campaigns & U.S. Army & July 8,1875 (A) \\
\hline PEASE, Joachim & Civil War & U.S. Navy & June $19,1864(\mathrm{~A})$ \\
\hline PENN, Robert & War with Spain & U.S. Navy & July 20, 1898 (A) \\
\hline PINN, Robert & Civil War & Colored Troops & April 2, 1865 (A) \\
\hline PITTS, Riley & Vietnam & U.S. Army & October 31, 1967 (P) \\
\hline RATCLIFF, Edward & Civil War & Colored Troops & September 29,1864 (A) \\
\hline RIVERS, Ruben & WWII & U.S. Army & January $13,1997(\mathrm{P})$ \\
\hline ROGERS, Charles & Vietnam & U.S. Army & May $14,1970(\mathrm{~A})$ \\
\hline SANDERSON, Aaron & Civil War & U.S. Navy & June $22,1865(\mathrm{~A})$ \\
\hline SARGENT, Ruppert & Vietnam & U.S. Army & March 15, $1967(\mathrm{P})$ \\
\hline SASSER, Clarence & Vietnam & U.S. Army & January 10, $1968(\mathrm{P})$ \\
\hline SHAW, Thomas & Indian Campaigns & U.S. Army & December 7, 1890 (A) \\
\hline SIMS, Clifford & Vietnam & U.S. Army & February 21, $1968(\mathrm{P})$ \\
\hline SMITH Andrew & Civil War & U.S. Army & January $16,2001(\mathrm{P})$ \\
\hline SMITH, Frank E. & China & U.S. Navy & June $20,1900(\mathrm{~A})$ \\
\hline SMITH, John & on-Combat 1871-1899 & U.S. Navy & September 19,1880 (A) \\
\hline
\end{tabular}




\begin{tabular}{|c|c|c|c|}
\hline STANCE, Emanuel Ind & dian Campaigns & U.S. Army & May $20,1870(\mathrm{~A})$ \\
\hline STOWERS, Freddie & WWI & U.S. Army & April 24, 1991 (P) \\
\hline SWEENEY, Robert Nor & on-Combat 1871-1899 & \multicolumn{2}{|c|}{ U.S. Navy October 26,1881; December 20,1883(P) } \\
\hline THOMAS, Charles & WWII & U.S. Army & January $13,1997(\mathrm{P})$ \\
\hline THOMPKINS, William & War with Spain & U.S. Army & June 23, 1899 (A) \\
\hline THOMPSON, William & Korean War & U.S. Army & June $21,1951(\mathrm{P})$ \\
\hline VEAL, Charles & Civil War & U.S. Colored Troops & April 6, 1865 (A) \\
\hline WALLEY, Augustus & Indian Campaigns & U.S. Army & August 16,1881 (A) \\
\hline WANTON, George & War with Spain & U.S. Army & June 30,1898 (A) \\
\hline WARD, John & Indian Campaigns & U.S. Army & August 16, 1881 (A) \\
\hline WARREN, John & Vietnam & U.S. Army & January 14, $1969(\mathrm{P})$ \\
\hline WATSON, George & WWII & U.S. Army & January 13, $1997(\mathrm{P})$ \\
\hline WILLIAMS, Moses & Indian Campaigns & U.S. Army & August 16,1881 (A) \\
\hline WILSON, William & Indian Campaigns & U.S. Army & August 1890 (A) \\
\hline WOODS, Brent & Indian Campaigns & U.S. Army & August 19,1881 (A) \\
\hline
\end{tabular}




\section{BIBLIOGRAPHY}

\section{PRIMARY SOURCES}

\section{BOOKS}

Binkin, Martin. Blacks and the Military. Washington, DC: Brookings Institution, 1982.

Brauer, Carl. John F. Kennedy and the Second Reconstruction. New York: Columbia University Press, 1977.

Brown, Nikki L.M and Barry M. Stentiford. The Jim Crow Encyclopedia: Greenwood milestones in African American History. Westport, CT: Greenwood Press, 2008.

Controvich, James T. African-Americans in Defense of the Nation: A Bibliography. Lanham: Scarecrow Press, 2011.

Dorn, Edwin, ed. Who Defends America? Race, Sex, and Class in the Armed Forces. Washington: Joint Center for Political Studies Inc., 1989.

Eagles, Charles W., ed. The Civil Rights Movement in America: Essays. Jackson: University Press of Mississippi, 1986.

Gomez, Julissa. Medal of Honor Recipients: 1979-2008. Washington: Congressional Research Service, The Library of Congress, 2008.

Holm, Jeanne. Women in the Military: An Unfinished Revolution. Novato, CA: Presidio Press, 1982.

Johnson, Shoshana. I'm Still Standing: From Captive U.S. Soldier to Free Citizen-My Journey Home. New York: Simon \& Schuster, Inc., 2010.

MacGregor, Morris, "Armed Forces Integration-Forced or Free?" in The Military and Society, edited by David MacIsaac. Washington: Office of Air Force History, 1975.

McNamara, Robert S., The Essence of Security: Reflection in Office. New York: Harper \& Row, 1968.

Nalty, Bernard C. and Morris J. MacGregor. Blacks in the Military: Essential Documents. Delaware: Scholarly Resources Inc., 1981.

National Research Council. Attitudes, Aptitudes, and Aspirations of American Youth: Implications for Military Recruitment. Washington, DC: National Academies Press, 2003.

Office of the Deputy Assistant Secretary of Defense for Equal Opportunity and Safety Policy, Dept. of Defense. Black Americans in defense of our nation. Washington, DC: Diane Publishing Company, 1985. 
Proft, R.J. United States of America's Congressional Medal of Honor Recipients and Their Official Citations. Columbia Heights, MN: Highland House II, Inc., $4^{\text {th }}$ edition, 2002.

Roster, Bernard. I Want You: The Evolution of the All-Volunteer Force. Santa Monica, CA: Rand Corporations, 2006.

Smith, Jessie Carnie. Black First: 4,000 Ground-Breaking and Pioneering Historical Events. Michigan: Visible Ink Press, $3^{\text {rd }}$ edition, 2013.

Smith, David Barton. Health Care Divided: Race and Healing a Nation. Ann Arbor: University of Michigan Press, 1999.

Stanford, Karin L., ed. If We Must Die: African American Voices on War and Peace. Maryland: Rowan \& Littlefield Publishers, Inc., 2008.

Tarver, Ron and Yvonne Latty. We Were There: Voices of African American Veterans, from World War II to The War in Iraq. New York: HarperCollins Publishers, Inc., 2004.

U.S. Bureau of the Census, Census 2000 Special Reports, Series CENSR-4. Demographic Trends in the Twentieth Century, by Frank Hobbs and Nicole Stoops. Washington DC: U.S Government Printing Office, 2002.

U.S. Department of Commerce, Bureau of the Census. The social and economic status of the Black population in the United States: An historical view, 1790-1978, by Manuel D Plotkin. Washington, D.C: U.S Government Printing Office, 1979.

U.S Department of Commerce. 1990 Census of Population and Housing, prepared by the Economics and Administration of the Bureau of the Census. Washington, D.C: U.S Government Printing Office, 1992.

U.S. Department of Defense. Task Force on the Administration of Military Justice in the Armed Forces. Washington: U.S. Government Printing Office, 1972.

Women's Research and Education Institute (WREI). Active Duty Service Personnel by Branch of Service, Officer/Enlisted Status and Sex as of 30 September 2003. Washington, DC: WREI, 2003.

Yarmolinsky, Adam. The Military Establishment: It's Impact on American Society. New York: Harper \& Row Publishers, 1971.

\section{WEB SITES}

Defense Manpower Data Center (DMDC). "Statistics and Reports." Collects and maintains an archive of manpower, personnel, training, and financial databases in the Department of Defense (DoD). www.dmdc.osd.mil 
Department of Defense. "DOD Directives." The Official Department of Defense Website for DOD Issuances. http://www.dtic.mil/whs/directives/corres/dir.html (accessed January 19, 2016).

National Archives and Records Administration. "President Harry S. Truman Desegregating the Military." Harry S. Truman Library and Museum. http://www.trumanlibrary.org/anniversaries/desegblurb.htm (accessed March 2, 2015).

United States Department of Labor Office of Policy Planning and research. "The Negro Family: The Case for National Action." United States Department of Labor http://ww.dol.gov/dol/aboutdol/history/ webid-meynihan.htm (accessed Jan 23, 2015).

United States Department of Labor Bureau of Labor and Statistics. "Employment Status of the civilian population by race, sex and age."

http://www.bls.gov/news.release/empsit.t02.htm (accessed April 25, 2015).

United States Department of the Interior. "The African American Legacy and the Challenges of the 21st Century." Office of Civil Rights. https://www.doi.gov/pmb/eeo/AA-HM\#main-content (accessed January 19, 2016).

\section{MAGAZINES}

Andrews, Michael A., Maj. UNA. "Women in Combat." The Military Review, July 1979, $28-34$.

Armor, David J. "Race and Gender in the U.S. Military." Armed Forces \& Society, Vol 23, No. 1, 1996.

Johnson, John H. ed. "Jill Brown May Be First Black Woman Navy Pilot." Jet, Vol. 48 No.5, October, 1974.

Johnson, John H. ed. "AME minister, Rev. Alice M. Henderson, blazes trail for women clerics." Ebony, Vol. 30, No.12, October, 1975.

Johnson, John. H. ed. “Admiral Gravely to Lead U.S. Navy’s Third Fleet.” Jet, Vol 50, August, 1976

Tilghman, Andrew. "All combat jobs open to women in the military." Military Times, December 3, 2015.

\section{JOURNALS}

Parks, Katie E., Andre T. Carswell and Russell N. James III. "Residential Satisfaction of Military Household in Privatized Apartment Communities," Housing and Society, (November 1, 2009 Vol 36): 95-114. 
Ripple, Bryan. "DEOMI Marks $40^{\text {th }}$ Year of Equity Training and Research Today," Defense Equal Management Opportunity Institute, (June 24, 2011 No. 11-0618):1-2.

\section{SECONDARY SOURCES}

\section{BOOKS}

Astor, Gerald. Right to Fight: A History of African Americans in the Military. Cambridge, MA: Da Capo Press, 1998.

Buckley, Gail and David Halberstam. American Patriots: The Story of Blacks in the Military from the Revolution to Desert Storm. New York: Random House, 2002.

Cothran, John C. A Search of African American Life, Achievement and Culture. Texas: Stardate Publishing, 2006.

Fisher, Perry and Brooks E. Gray. Blacks and Whites Together Through Hell. Turlock, California: Millsmont Publishing, 1993.

Fletcher, Marvin. America's First Black General. Lawrence: University Press of Kansas, 1989.

Foner, Jack D. Blacks and the Military in American History. New York: Praeger, 1974.

Johnson, Jesse. Black Women in the Armed Forces, 1942-1974: A Pictorial History. Hampton, Va.: Johnson C., 1974.

Krebs, Ronald R., Fighting for Rights: Military Service and the Politics of Citizenship. New York: Ithaca, 2006.

MacGregor, Morris J. Integration of the Armed Forces, 1940-1965. Charleston: Create Space, 2014.

Mershon, Sherie and Steven Schlossman. Foxholes \& Color Lines: Desegregated the U.S. Armed Forces. Baltimore: The John Hopkins University Press, 1998.

Myrdal, Gunnar, Richard Sterner, and Arnold Rose. An American Dilemma: The Negro Problem and modern democracy. New York: Harpers y Brothers Publishers, 1944.

Sowell, Thomas. The Economics and Politics of Race: An International Perspective. New York: William Morrow and Company, 1983.

- Civil Rights: Rhetoric or Reality? New York: William Morrow and Company, 1984. 
Stillwell, Paul. The Golden Thirteen. Annapolis: Naval Institute Press, 1993.

West, Cornel. Race Matters. Boston: Beacon Press, 1993.

Williams, Walter E. The State against Blacks. New York: New Press, McGraw-Hill, 1982.

\section{JOURNALS}

Vaughan, Don. "Changing Tunes.” Military Officer, February 2015, 52-55.

\section{NEWSPAPERS}

"Integration Brought Strength, Credibility to Military," American Forces Press, July, 22, 2008. 